\title{
De eerste gazettiers en hun kranten in de Spaanse Nederlanden
}

door

\author{
Prof. Dr. Theo LUYKX
}

Onder de produkten van de drukkunst, sedert het midden van de $15 \mathrm{e}$ eeuw op de markt gebracht, kunnen het boek en het vlugschrift op een merkelijk oudere geschiedenis bogen dan de gedrukte krant. $\mathrm{Na}$ de uitvinding van de boekdrukkunst duurde het inderdaad nog nagenoeg 150 jaar vooraleer het eerste drukwerk verscheen, dat de naam van "krant" verdient. De uitvinding van de boekdrukkunst brengt ons immers terug tot in de Boergondische tijd, terwijl de eerste kranten in de Zuidelijke Nederlanden slechts opdoken tijdens de Spaanse overheersing, inzonderheid tijdens het bewind van de aartshertogen Albrecht en Isabella.

Voor dit opvallend verschijnsel bestaat ongetwijfeld een verklaring, die in de eerste plaats verband houdt met de wezenskenmerken van de krant. De krant is inderdaad een drukwerk met zeer bijzondere eigenschappen. Naar haar inhoud is zij bij bepaling afgestemd op de actualiteit; in haar verschijnen onderwerpt zij zich aan een vaste periodiciteit ; zij bezit een continu karakter, d.w.z. dat elk nummer thuishoort in een ononderbroken reeks van publicaties met dezelfde titel, een doorlopende numerotering, enz.; zij bezit vervolgens het karakter van de „openbaarheid" of de ,publiciteit", d.w.z. dat zij voor iedereen toegankelijk is en niet gemaakt voor een afgesloten groep of privé-personen. Tenslotte kan men, althans van de moderne krant zeggen dat zij naar haar inhoud een universeel karakter bezit, d.w.z. dat zij op encyclopedische wijze alle terreinen van het menselijk denken en handelen wenst te overschouwen ${ }^{1}$.

De twee onmiddellijke voorlopers van de gedrukte krant waren de geschreven courantbrief en het gedrukte vlugschrift. De geschreven nieuwsverspreiding, waarvan de koopmansbrieven ${ }^{2}$ de belang-

(1) Over de eigenschappen van de krant bestaat, inzonderheid langs Duitse zijde, een uitvoerige literatuur. Cf. E. Dovifat: Zeitungswissenscbaft, Berlijn, 1931; O. Groth: Dei Zeitung. Ein system der Zeitungskunde, Manheim-Berlin-Leipzig, 4 din, 1928-1930; W. Hagemann : Die Zeitung als Organismus, Heidelberg, 1950; N. Devolder: De Ethiek van de Pers, Leuven, 1952.

(2) Hieronder vooral de zg. "Fuggerzeitungen" - V. Klarwill : The Fugger Newsletters, 2 dln, Londen, 1924-1926. 
rijkste groep vormen, miste in feite het kenmerk van de openbaarheid, terwijl het vlugschrift wel voldoende publiciteit verwierf, doch accidenteel, naar aanleiding van een bepaalde gebeurtenis verscheen en zich dus niet aan een vaste periodiciteit onderwierp. Vooraleer nu onze uitgevers van vlugschriften de gewichtige beslissing namen om hun lezerspubliek op regelmatige tijdstippen op de hoogte te houden van wat er waaide en draaide, ook als er niets bijzonders gebeurde, verliep er meer dan een eeuw tijd.

De overgang van het vlugschrift naar de krant beschreef dus een lange weg, doch deze verliep zo geleidelijk dat op een bepaald ogenblik de grens tussen beiden moeilijk is te ontwaren. Sedert de $16 e$ eeuw dragen heel wat niet-periodieke ,nieuwstijdingen" dezelfde titels als de eerste kranten, nl. "Tydinghe”, "Nyeuwe Tydinghe", "Varachtige Tydinghe", "Wonderlijcke Tydinghe" enz. ${ }^{3}$. Anderzijds stelt het probleem van de periodiciteit zelf moeilijkheden : de publikaties met een jaarlijkse, halfjaarlijkse of maandelijkse periodiciteit kunnen opklimmen tot het einde der 16e eeuw ${ }^{*}$. Wij laten hier deze periodische publikaties buiten beschouwing, omdat de eerste werkelijke kranten, althans in onze gewesten, minstens een wekelijkse periodiciteit vertonen. De door de Spaanse Overheid erkende gazettiers publiceerden hun krant wekelijks en zelfs spoedig tweemaal in de week.

Voor het opsporen van de oudste kranten in West-Europa heeft de Zweedse geleerde Folke Dahl ongetwijfeld pionierswerk verricht. Zijn opsporingen zijn o.m. gericht geweest op het belangrijkste krantencentrum Amsterdam en de oudste courantiers aldaar, Caspar Van Hilten en Broer Janszoon. Ook voor de eerste Antwerpse gazettiers - Abraham Verhoeven, Willem Verdussen en Martin Binnart - heeft hij grote belangstelling gehad. Zijn studies zijn echter hoofdzakelijk bibliothecariswerk, d.w.z. dat hij met een bewonderenswaardige speurzin de nog bestaande nummers van oude kranten heeft geïnventariseerd en beschreven ${ }^{5}$. Zijn werk moet

(3) R. Van Sint-Jan: Over oude nieuwstijdingen. Het Boek, jg. 17, 1928, pp. 102-114. L. Voet: Abrabam Verboeven en de Antwerpse Pers. De Gulden Passer, 1953, p.1-37. Zie verder voorbeelden in: Bibliotbeca Belgica. Bibliograpbie générale des Pays-Bas, Gent-Den Haag, 1891-1923; M.F. Cambell : Annales de la typograpbie néerlandaise au XVe siècle, 5 dln (waarvan 4 in supplement), Den Haag, 18741890 ; W. Nijhoff en M.E. Kronenberg: Nederlandscbe Bibliographie, 2 dln, Den Haag, 1923-1936.

(4) Wij denken o.m. aan de halfjaarlijkse "Relatio bistorica" of de zg. "Meszrelationen" van Michael von Aitzing, verschenen tussen 1583 en 1593 als halfjaarlijkse publicatie en van 1594 tot 1597 als jaarboek. - F. Stieve : Ueber die ältesten balbjäbrigen Zeitungen oder Meszrelationen und insbesonders über deren Begründer, Freih. Michael von Aitzing. Abhandl. der $3 \mathrm{Kl}$. der kaiserl. Akad. der Wissenschaften, 16, Bd. 1, 1881.

(5) Folke Dahl : Amsterdam, earliest Newspaper Centre of Western Europe, Den Haag, 1939; Dutcb Corantos, 1618-1650, Den Haag, 1946; A bibliograpby of En- 
echter aangevuld worden, niet alleen door het verder opsporen van oude krantennummers, maar vooral door het aansnijden van een andere soort historische bronnen, $\mathrm{nl}$. de archiefbronnen. Zo berusten bv. op het Algemeen Rijksarchief te Brussel tal van bundels, die o.m. de teksten van de octrooien van onze gazettiers in de Spaanse tijd bevatten. Het is niet uit de toevallig bewaarde nummers van hun kranten, maar wel uit deze documenten dat men met zekerheid opmaken kan wanneer een bepaalde gazettier met de toestemming van de overheid aan het werk toog en hoe en wanneer zijn octrooi in andere handen overging. Een aaneenhangend relaas van de activiteit van onze eerste gazettiers is maar te schrijven op basis van genoemde twee soorten bronnen: de bewaarde kranten en het documentenmateriaal, dat in onze verschillende archiefdepots nog aanwezig is.

Dit werk houdt ons sedert geruime tijd bezig en het is hier onze bedoeling enkele resultaten van deze opzoekingen samenvattend mede te delen.

\section{De vier zetelplaatsen van bevoorrechte gazettiers}

Bij het ontstaan van de krant in de Spaanse Zuidelijke Nederlanden hebben vier grote steden een belangrijke rol gespeeld. Achtereenvolgens werden Antwerpen, Brugge, Brussel en Gent zetelplaatsen van drukkers, die van de Spaanse overheid een speciaal octrooi ontvingen voor het uitgeven van een krant.

Antwerpen was niet alleen de eerste zetelplaats van een gepriviligieerd gazettier, maar werd de enige stad, waar verschillende kranten tegelijkertijd door houders van krantenoctrooien werden uitgegeven. De drie drukkersfamilies, die gelijktijdig als krantenuitgevers werkzaam zijn geweest, waren de families Verhoeven, Verdussen en Binnart.

Indien aan Abraham Verhoeven nog moeilijk de titel van ,eerste gazettier" "van Europa kan toegekend worden ${ }^{7}$, dan was hij toch in elk geval de eerste gazettier in de Spaanse Zuidelijke Neder-

glisb corantos and periodical newsbooks, 1620-1642, Stockholm, 1953; Nouvelles contributions à l'bistoire des premiers journaux d'Anvers. La Chronique graphique, 5 maart, 1939.

(6) Cfr. A. Goovaerts: Abrabam Verboeven d'Anvers, le premier gazettier de l'Europe, Antwerpen, 1880 ; E. De Bom: Abrabam Verboeven, de eerste courantier van Europa? Tijdschrift voor Boek- en Bibliotheekwezen, jg. I, 1903, p. 27-51.

(7) De eerste kranten met een wekelijkse periodiciteit dateren van 1609 en stammen uit Duitsland. Het betreft de protestantse Aviso, Relation oder Zeitung, gedrukt te Wolfenbüttel, en de katholieke Relation uit de Rijnstreek. Beiden werden in fac-similedruk heruitgegeven. - Walter Schoene: I. Der Aviso des Jabres 1609, Leipzig, 1939 ; II. Die Relation des Jahres 1609, Leipzig, 1940. 
landen. Ook al weigert men in zijn talrijke publikaties tussen 1605 en 1629 - die hij dikwijls "Nieuwe Tydingben” noemt - al de wezenskenmerken te onderscheiden van een echte krant, dan staat het toch vast dat zijn "Wekelycke Tydinghe", die hij tussen 27 juni 1629 en 18 juni 1631 publiceerde ${ }^{8}$, het eerste periodiek druksel is, dat in de Spaanse Nederlanden onomstootbaar de naam van krant verdient.

Toen op 18 juni 1631 het laatste gekende nummer van zijn "Wekelijcke Tijdinghe" verscheen, stelde Abraham Verhoeven daarom geen einde aan zijn publicistische arbeid. De Zweedse pershistoricus Folke Dahl kon inderdaad de hand leggen op een serie nieuwsblaadjes, die nu bewaard worden in de Koninklijke Bibliotheek te Stockholm. De elf bewaarde ktanten in klein infolioformaat (van slechts 2 pagina's) heten alle "Courante", maar vijf dragen als volledige titel "Courante uyt Duytschlandt, etc.", vier "Courante uyt Nederlandt, etc.", één "Courante uyt Frianckrijck, etc." en één "Courante uyt Polen, etc.". Zij werden, evenals de "Wekelijcke Tijdinghe", gedrukt te Antwerpen bij Abraham Verhoeven , in de gulde handt, op de Lombaerde Veste" ${ }^{9}$. Deze elf bewaarde nieuwsblaadjes werden gedrukt tussen 10 maart 1632 en 6 september 1632 .

De tweede Antwerpse gepriviligieerde gazettier was Willem Verdussen, die zijn krantenoctrooi ten laatste in 1635 ontving, dus op een ogenblik dat de familie Verhoeven, inzonderheid de weduwe van Izaak Verhoeven, nog steeds een krant publiceerde ${ }^{10}$. Van de Extraordinaris Post-tijdinghen van Willem Verdussen had Folke Dahl 60 nummers teruggevonden, die berusten in de Kon. Bibliotheek te Stockholm en de Bibliothèque Mazarine te Parijs. Ondertussen konden wij vaststellen dat er op de Stadsbibliotheek van Brugge nog 25 ongekende nummers voorkomen, samengebonden met de 83 nummers van de eerste Brugse krant van Nicolaas Breyghel, waarover wij verder handelen. De 85 nu gekende nummers van de Extraordinaris Post-tijdinghen van de familie Verdussen dateren van 8 juni (nr. 14) 1635 tot 23 augustus 1661. Wij weten echter dank zij archiefdocumenten dat de krant ook na 1661 bleef

(8) De verzameling berust op de Kon. Bibliotheek te Brussel in het fonds „Kostbare Werken".

(9) Folke Dahl : Nouvelles contributions à l'bistoire des premiers journaux d'Anvers. La Chronique graphique, 5 maart 1939, pp. 4303-4304.

(10) De weduwe van Izaak Verhoeven publiceerde nog op 24 april 1637 een nagenoeg gelijknamige krant: "Extraordinarisse Posttydinghe des Jaers 1637, ghedruckt den 24 April". Op de tweede bladzijde onderaan staat duidelijk gedrukt: "'t Antwerpen bij de weduwe van Isaac Verhoeven op de Lombaerde Veste inde Gulde Sonne" - Dit nummer wordt bewaard op de Stadsbibliotheek te Brugge, samengebonden met de 83 nummers van de Nieuwe Tydingben uyt verscheyde ghewesten van Nicolaas Breyghel. 
verschijnen. Uit een bewaard schrijven van de Antwerpse stadsmagistraat van 29 maart $1672^{11}$ vernemen wij dat Pieter Verdussen op dat ogenblik octrooihouder was van de krant, terwijl uit een gerechtelijk onderzoek van april 1689 blijkt dat de krant van Verdussen op dat ogenblik ook te Brussel aan de man werd gebracht ${ }^{12}$. De krant bleef tot 4 februari 1695 toebehoren aan de familie Verdussen ; toen werd zij door Jacob Verdussen verkocht aan de Antwerpse drukker Hendrik Aertsen ${ }^{13}$. Op dat ogenblk had de krant reeds een andere titel aangenomen. Sedert $1691^{14}$ heette zij Antwerpsche Dijnsdaeghsche Post-tydinghe en Antwerpsche Vrijdaeghsche Post-tydinghe, naar gelang zij 's dinsdags of 's vrijdags van de pers kwam. Onder deze titel is zij blijven voortleven tot tijdens het Oostenrijks regime ${ }^{15}$.

Met Martin Binnart dook te Antwerpen de derde gazettier op, die naast de families Verhoeven en Verdussen ,met gratie ende privilegie" van de overheid een krant uitgaf en wel in de twee landstalen; naast Den Ordinarissen Postilioen publiceerde hij tevens Le Postillon Ordinaire. Op basis van de hem bekende nummers kon Folke Dahl concluderen dat de kranten van Binnart op zijn minst tussen 1639 en 1646 te Antwerpen verschenen ${ }^{16}$. Uit de bewaarde archiefbronnen kan echter duidelijk worden opgemaakt dat Binnart zijn octrooi ontving op 22 november $1635^{17}$; anderzijds bevat de bovengenoemde bundel oude kranten op de stadsbibliotheek te Brugge een nummer van 21 april 1637, terwijl het oudste tot nogtoe gekende nummer op de Bibliothèque Mazarine te Parijs slechts dateert van 19 augustus 1639 . Ook staat vast dat de kranten van Martin Binnart nog lang na 1646 bleven verschijnen, ook al ontbreekt het ons na deze datum aan bewaarde nummers. Hijzelf moet in de aanvang van 1658 overleden zijn, doch op 8 maart 1658 ontvingen zijn weduwe en zijn kinderen van de Spaanse overheid de toelating om de krant verder te zetten en dit octrooi werd in

(11) Brussel, Algemeen Rijksarchief, Conseil privé espagnol, doos 1279.

(12) Brussel, Algemeen Rijksarchief, Conseil d'Etat, bundel 1846.

(13) Cfr. F.J. Van den Branden: Ontstaan van bet Nieuwsblad te Antwerpen. Abrabam Verboeven. Zijn leven (1575-1652), Antwerpen, 1902, p. 38.

(14) F.J. Van den Branden (o.c., p. 38-39) zegt dat deze naamverandering werd aangebracht door Hendrik Aertsen in 1695. De krant droeg echter deze titel reeds in 1691, zoals blijkt uit het nummer van 28 augustus 1691 (nr. 68 van dat jaar), bewaard op het Stadsarchief te Antwerpen.

(15) Op 3 januari 1719 nam de krant de titel van Gazette van Antwerpen, waarvan de jaargangen (1719-1804) bewaard bleven op het Stadsarchief te Antwerpen.

(16) Folke Dahl : Nouvelles contributions, p. 4310.

(17) Martin Binnart geeft deze datum zelf op in zijn schrijven aan de Spaanse koning in de aanvang van 1648 - Brussel, Alg. Rijksarchief, Conseil privé espagnol, doos 1280 . 
1668 andermaal voor 10 jaar verlengd ${ }^{18}$.

$\mathrm{Na}$ Antwerpen werd Brugge de tweede zetelplaats van een door de Spaanse Overheid geprivilegieerde gazettier in de persoon van Nicolaas Breyghel. Als drukker was hij in 1624 van Antwerpen naar Brugge verhuisd ${ }^{19}$ en had in de Scheldestad zonder twijfel kennis gemaakt met de Nieuwe Tydinghen van Abraham Verhoeven. Het is dan ook niet te verwonderen dat hij zijn krant te Brugge de titel schonk van Nieuwe Tydinghen uyt verscheyde ghewesten ${ }^{20}$. Van zijn krant bleven op de Stadsbibliotheek 83 nummers bewaard, gaande van 24 maart (nr. 12) 1637 tot 24 januari (nr. 4) 1645. Men heeft herhaaldelijk beweerd dat de Zwinstad na het verdwijnen van Breyghel geen gazettiers meer zou hebben gehad. De onjuistheid van deze stelling werd nog onlangs door de Brugse stadsarchivaris $A$. Schouteet ${ }^{21}$ op overtuigende wijze bewezen en wijzelf hebben kunnen uitmaken op grond van archiefdocumenten dat de Brugse gazettiers tijdens de Spaanse overheersing ten minste tot in 1678 aan het werk bleven ${ }^{22}$.

Op het eerste gezicht baart het verwondering dat Brussel, de hoofdplaats van de Spaanse Nederlanden, slechts na Antwerpen en ook na Brugge de zetelplaats werd van een geprivilegieerd gazettier. De eerste gazettier, waarvan wij het octrooi kennen, was inderdaad Pierre Hugonet, die slechts sedert 1649 optrad met de krant Le Courrier véritable des Pays-Bas, waarvan het eerste nummer op 28 augustus 1649 van de pers kwam ${ }^{23}$. Wel staat het vast dat te Brussel reeds voordien periodieke publikaties verschenen, zoals "Recite Véritable”, gedrukt bij Jan Mommaert ${ }^{24}$. Het lijkt ons echter niet verantwoord deze nieuwstijding handelend over één bijzondere gebeurtenis, als de eerste Brusselse krant voor te stellen. Een speciaal probleem blijft de zg. Brusselsche Gazette, waarmede

(18) Dit blijkt uit een schrijven van het Antwerps magistraat van 29 maart 1672. Ibidem, doos 1279.

(19) A. Visart de Bocarmé, Recberches sur les imprimeurs brugeois, Brugge, 1928, p. 38 .

(20) Deze titel doet tevens denken aan de titel van de krant van de Hollandse courantier Broer Janszoon "Tydingben uyt verscheyde Quartieren".

(21) A. Schouteet : Nieuwsbladen te Brugge in de $17 e$ eeuw. Hand. Société d'Emulation te Brugge, dl. XCIX, 1962, p. 83-90.

(22) Th. Luykx: Brugse kranten en gazettiers in de Spaanse Nederlanden. Hand. Société d'Emulation te Brugge (in druk).

(23) De volledige en gebonden eerste jaargang van "Le Courier véritable" berust op de Kon. Bibliotheek te Brussel, afdeling "Kostbare Werken".

(24) De volledige titel luidt: „September $1626.100 /$ Recite /Véritable / de l'entreprinse faillie/ Que les Hugenots avoient conspiré sur/les limites de flandres y pensant empor l ter Kildaecbt, mais ont esté contrains de / se retirer averq leur bat. teaux / Faict le 29. d'Aougst, 1626". Op de voorpagina wordt een voorstelling van deze mislukte aanval afgebeeld en hieronder staat gedrukt: "A Bruxelles, chez Jean Mommaert". Dergelijke "nieumaren" werden door Abraham Verhoeven met tientallen verspreid. 
Nicolaas Breyghel sedert 1637 zijn Brugse krant telkens afsluit. Het is nl. niet duidelijk of het hier een Brusselse correspondent van Breyghel betreft ofwel een Vlaamse Brusselse krant, die door Breyghel telkens wordt geëxcerpeerd.

De eerste goedgekende en volledig bewaarde Brusselse krant "Le Courrier véritable des Pays-Bas", die op 14 mei 1650 haar titel wijzigde in "Relations véritables", werd bij herhaling toegeschreven aan de Brusselse drukker Jan Mommaert II ${ }^{25}$. De 7 eerste nummers werden inderdaad bij hem gedrukt, doch de octrooihouder van deze krant was zonder enige twijfel Pierre Hugonet, advocaat bij het Parlement van Dôle in Boergondië ${ }^{26}$. Evenals de meeste andere gazettiers in de Spaanse Nederlanden maakte Hugonet slechte zaken met zijn krant. Om uit zijn financiële moeilijkheden te geraken verzocht hij o.m. de Spaanse Koning in 1655 hem een exclusief octrooi te verlenen, dat hem het recht zou geven om als enige gazettier in geheel de Spaanse Nederlanden te fungeren. Hierin slaagde hij. Zijn tweede octrooi van 20 november $1655^{27}$ schonk hem, althans op papier, deze monopoliepositie; wat vanzelfsprekend aanleiding gaf tot een conflict met de gazettiers uit de andere steden, die niet werkloos wilden vallen. Op dit conflict, dat zijn hoogtepunt bereikte onder de opvolger van Hugonet, de Brusselse geneesheer-gazettier Adriaan Foppens, komen wij later nog terug.

Als zetelplaats van een geprivilegieerd gazettier kwam Gent pas op de vierde plaats, na Antwerpen, Brugge en Brussel. Dit belet niet dat de "Ghendtsche Post-tydingbe", die de Gentse drukker Maximiliaan Graet wellicht sedert 1 januari 1667 van de pers liet komen ${ }^{28}$, het langste bestaan zal kennen. Tot in 1940, datum van haar verdwijnen, ging de "Gazette van Gent", de rechtstreekse opvolgster van de Ghendtsche Post-tydinghe, door voor de oudste nog bestaande krant ter wereld ${ }^{29}$. Uit het rekwest van de Gentse drukker Maximiliaen Graet van 17 augustus 1666 om van de over-

(25) Bv. A. Warzée (Essai bistorique et critique sur les Journaux belges, GentBrussel, 1845, p. 12); V. Brants (Le régime légal des journaux dans les anciens PaysBas belges. Revue Générale, 1915, p. 46-48); L. Galesloot (Mémoires secrets d'A. drien Foppens sur le gouvernement et les affaires des Pays-Bas pendant les années 1680-1682. Bull. Com. Roy. Histoire, 4e serie, t. IV, 1877, p. 371, nota 2) ; M. Cordemans (Het oudst-bewaard nieuwsblad te Brussel. Eigen Schoon en De Brabander, XVII, nr. 7, 1935, p. 247 vlg.).

(26) $\mathrm{Zijn}$ eerste octrooi dateert van 12 oktober 1649 en was geldig voor 9 jaar. Brussel, Algemeen Rijksarchief, Conseil privé espagnol, doos 1279.

(27) Ibidem, doos 1280.

(28) Het eerst bewaard nummer is nr. 69 van 8 september 1667. - Gent, Universiteitsbibliotheek.

(29) $\mathrm{Na}$ het verdwijnen van de Gazette van Gent bij het uitbreken van W.O. II, is waarschijnlijk de Worcester Journal, gesticht in 1690 , de ouderdomsdeken van de pers. 
heid de toelating te bekomen een krant uit te geven ${ }^{30}$ alsmede uit de hierbij aansluitende gunstige adviezen van de Raad van Vlaanderen en van de Gentse schepenen van de Keure blijkt dat de weduwe Kerckhove en ook andere drukkers reeds vóór 1666 te Gent ,wekelicke relaesen ofte gasetten v'an nieuwe tydinghen" hadden laten verschijnen. Er moet dus reeds vóór het optreden van Graet een periodiek druksel te Gent hebben bestaan, doch van een door de Spaanse overheid erkende gazettier vóór hem wordt nergens gerept. Het octrooi van Graet dateert van 17 november $1666^{31}$ en wij mogen aanvaarden dat hij zijn Gendtsche Post-tydinghe sedert 1 januari 1667 regelmatig op de markt bracht ${ }^{32}$. Hij overleed in 1676, doch het octrooi van zijn krant bleef gedurende heel de Spaanse tijd aan zijn familie toebehoren.

\section{De Brusselse gazettier contra al de overigen}

Dat de gazettiers van de verschillende steden zo herhaaldelijk onderling of tegen drukkers in hun eigen stad van leer trokken, hield verband met het feit dat zij de hun bij octrooi geschonken monopoliepositie binnen hun stad of gewest verdedigden.

Sedert 20 november 1655 bestond er echter in de Spaanse Nederlanden een onmogelijke toestand. De Brusselse gazettier Pierre Hugonet ontving op die datum van de Spaanse overheid het exclusief octrooi om als enige gazettier voor heel de Zuidelijke Nederlanden te fungeren en dit zowel wat betreft de franstalige als de Vlaamse kranten ${ }^{33}$.

De strikte toepassing van dit exclusief octrooi moest dus een einde stellen aan de werkzaamheden van alle andere gazettiers : te Antwerpen, Brugge en Gent. Zowel Pierre Hugonet als zijn opvolger Adriaan Foppens wilden dit gedaan krijgen, doch het spreekt vanzelf dat de gazettiers uit de andere grote provinciesteden zich niet weerloos hebben laten doen. In deze strijd tegen de Brusselse gazettier ontvingen zij trouwens de kordate steun van hun respectievelijke stadsbesturen.

(30) F. Vander Haeghen : Bibliograpbie Gantoise (6 dln, Gent, 1861-1865), dl. VI, p. 108-109.

(31) Deze datum staat o.m. vermeld in een advies van de Raad van State van 15 september 1672. - Brussel, Algemeen Rijksarchief, Conseil d'Etat, bundel 1846.

(32) Het eerste bewaarde nummer dateert slechts van 8 september 1667 en heeft het volgnummer 69 (Gent, Universiteitsbibliotheek).

(33) "octroyons... qu'il puisse et pourra luy seul à l'exclusion de tous autres, en toutes nos Provinces de pardeça, faire toutes les Relations de tout ce qui se passe et passera en ces pays et ailleurs, tant aux affaires de la guerre qu'autres, en langue Flamand, Fraņ̧ois et autres..."- Brussel, Alg. Rijksarchief, Conseil privé espagnol, doos 1280 . 
Over de pogingen van Pierre Hugonet om met de steun van de centrale overheid de andere gazettiers het zwijgen op te leggen, zijn wij tot nogtoe onvolledig ingelicht. Wij kennen alleen een verslag van een beraadslaging van de Raad van Brabant, dd. 7 augustus $1656^{34}$, waaruit blijkt dat Pierre Hugonet het offensief tegen de andere gazettiers had ingezet. Op 31 mei 1656 had hij zich gericht tot de Spaanse gouverneur-generaal opdat de overheid een einde zou stellen aan de krant van Hieronymus Verdussen uit Antwerpen, waarvan Hugonet te Brussel blijkbaar de meeste concurrentie ondervond. De Raad van Brabant nam blijkbaar de verdediging op van Verdussen en zijn krant werd dan ook niet geschorst.

$\mathrm{Na}$ het overlijden van Pierre Hugonet ontving Adriaan Foppens op 25 juni $1667^{35}$ het octrooi voor de "Relations véritables" en kreeg eveneens het exclusief monopolie om als enige gazettier in de Spaanse Nederlanden op te treden. Van de pogingen van de ondernemende gazettier Adriaan Foppens om de overige gazettiers in de Spaanse Nederlanden overboord te zetten, zijn wij heel wat beter ingelicht dan voor zijn voorganger. Om zijn doel te bereiken, ging hij in alles zeer voorzichtig te werk, wellicht omdat hij zich spiegelde aan de mislukking van Pierre Hugonet.

Einde 1671-begin 1672 richtte een zekere Zéleux - misschien was het Foppens zelf of ten minste iemand die in overleg met hem handelde - een rekwest tot de Spaanse koning. Hierin drukte hij zijn verwondering uit dat er andere gazettiers buiten Brussel aan het werk bleven, ofschoon Adriaan Foppens over patentes absolues beschikte. Het bestaan van andere gazettiers te Antwerpen, Gent en Brugge, zo zegt hij verder, leidt tot: plusieurs contradictions, scandales et autres inconvéniens très pernicieux au service de $S_{a}$ Majesté et du bien public ${ }^{36}$.

Als gevolg van dit rekwest liet de overheid een onderzoek instellen te Antwerpen, Brugge en Gent ${ }^{37}$ en na vele wederwaardigheden adviseerde de Raad van State op 15 september 1672 dat het inderdaad verkeerd was van nog andere gazettiers buiten Brussel aan het werk te laten. Adriaan Foppens zou als enige gazettier voor geheel de Spaanse Nederlanden moeten optreden, op voorwaarde echter dat hij ook zou uitgeven: ,des gazettes en flameng, pour la satisfaction de ceux qui ne scavent pas la langue françoi-

(34) Brussel, Algemeen Rijksarchief, Conseil de Brabant, Register A 271, $\mathrm{f}^{\circ} 79^{\circ}-80$.

(35) Brussel, Algemeen Rijksarchief, Conseil d'Etat, bundel 1844.

(36) Zeleux had zijn rekwest in drievoud opgesteld: het eerste was gericht tegen de gazettiers van Antwerpen, het tweede tegen die van Gent en het derde tegen die van Brugge. - Brussel, Algemeen Rijksarchief, Conseil privé espagnol, doos 1279 en Conseil d'Etat, bundel 1846.

(37) De documenten in verband met dit onderzoek berusten op het Algemeen Rijksarchief, Conseil d'Etat, bundel 1846 en Conseil privé espagnol, doos 1279. 
$s e^{38}$. Ingevolge dit advies gaf de Spaanse gouverneur-generaal Juan-Domingo de Zuñiga y Fonseca op 19 september 1672 opdracht aan de Spaanse Geheime Raad er voor te zorgen dat Foppens als enige gazettier aan het werk zou blijven, weshalve de kranten buiten Brussel dienden te worden opgeheven ${ }^{39}$.

Foppens scheen dus zijn slag te hebben thuisgehaald, doch tegen alle verwachting in werd de beslissing van de gouverneur-generaal nooit uitgevoerd. Blijkbaar hebben niet alleen de Raden van Brabant en Vlaanderen, maar vooral ook de stadsbesturen van Antwerpen, Gent en Brugge hun beschermende hand gehouden boven de bedreigde hoofden van hun gazettiers. Wegens het uitblijven van enige beslissing verliest Adriaan Foppens er zijn geduld bij en richt in 1673 een nieuw rekwest tot de Spaanse koning ${ }^{40}$, waarbij hij dus zijn Zéleux-anonymaat opgaf. Hierin drukt hij er zijn verwondering over uit dat de gazettiers van Antwerpen, Gent en Brugge maar steeds voortgaan met het publiceren van ,des gazettes en flamend" en dit trots ",une résolution si authentique de Votre Excellence sur une consulte du Conseil d'Etat". Opnieuw had, op bevel van de Spaanse centrale overheid, een onderzoek plaats in de drie Vlaamse gazettierssteden, doch de stadsmagistraten namen andermaal hun gazettiers onder hun bescherming en wierpen allerhande proceduremoeilijkheden op om te voorkomen dat dezen door een definitief verbod zouden getroffen worden ${ }^{41}$.

Brussel is er dus nooit in geslaagd om de gazettiers van de andere Vlaamse steden het zwijgen op te leggen. Adriaan Foppens heeft sedert 1676 zijn pogingen gestaakt en zijn opvolger, die evenals hijzelf nog steeds over een theoretisch ,exclusief" octrooi beschikten, hebben de gazettiers uit de drie andere steden der Spaanse Nederlanden met rust gelaten.

\section{Het statuut en de opdracht van de gazettier}

De gazettiers van het Ancien-Regime waren geen staatsambtenaren, zoals bv. journalisten in fascistische of communistische landen heden ten dage. De eerste gazettiers leefden echter in een tijd van vorstelijk absolutisme, dat elk optreden van de enkeling in het openbaar leven afhankelijk maakte van een goedkeuring der overheid. Deze goedkeuring werd vastgelegd in patenten en octrooien,

(38) Brussel, Algemeen Rijksarchief, Conseil d'Etat, bundel 1846.

(39) Brussel, Algemeen Rijksarchief, Conseil d'Etat, bundel 1846.

(40) Tekst bij F. Vander Haeghen: Bibliograpbie Gantoise, dl. II, p. 244.

(41) De documenten in verband met dit nieuw onderzoek in de Vlaamse steden berusten op het Algemeen Rijksarchief, Conseil privé espagnol, doos 1280. 
die de rechten en de verplichtingen van de octrooihouder nauwkeurig omschreven ${ }^{42}$.

De gazettier kon aanspraak maken op bescherming van zijn monopolie, waarvoor hij trouwens een koopsom had moeten storten in de staatskas, maar anderzijds was hij onderworpen aan een aantal verplichtingen. Als een hoofdverplichting gold: de onderwerping van de krantenkopij aan een preventieve censuur.

Toen de krant in de aanvang van de $17 \mathrm{e}$ eeuw haar eerste verschijning deed, waren in de vier steden - Antwerpen, Brugge, Brussel en Gent - reeds boekcensoren aan het werk, die toen overwegend tot de geestelijke stand behoorden. Aanvankelijk werd de censuur van de kranten aan deze reeds fungerende boekcensoren opgedragen, zoals blijkt uit de initialen L(ibrorum) C(ensor), die na de initialen van de censor zelf op de eerste kranten voorkomen.

De krantencensuur vereiste echter meer spoed dan de boekcensuur, zodat de overheid een beroep ging doen op speciale censors voor de krant. Geleidelijk zien wij op de eerste kranten het initiaal (Librorum) wegvallen, waaruit mag afgeleid worden dat de krantencensuur werd losgemaakt van de boekcensuur. Voor deze krantencensuur bleef de overheid trouwens geen beroep doen op de geestelijkheid, doch zij werd, reeds in de Spaanse tijd, hoofdzakelijk toevertrouwd aan staats- of stadsambtenaren ${ }^{43}$.

De censor had er in de eerste plaats op te letten dat geen berichten aan de publiciteit werden toevertrouwd, die de vorstelijke of staatsbelangen schaden konden. Soms kwam hij, niet steeds door zijn schuld, aan deze opdracht tekort en dan had niet alleen de censor maar ook de gazettier zelf met moeilijkheden vanwege de centrale overheid af te rekenen.

Een mooi voorbeeld hiervan beleven wij in 1681 met de Gbendtsche Posttydinghe, waarvoor de weduwe van Maximiliaan Graet toen het octrooi bezat ${ }^{44}$. De krant werd op koninklijk bevel van 12 november 1681 voor onbepaalde tijd geschorst. De aanleiding hiertoe was een correspondentie uit Den Haag van 6 november, die

(42) Th. Luykx : De Gazettiers en bun octrooien tijdens het Ancien Régime. Handel. van het XXIVe Vlaams Filologencongres, april 1961, p. 436-447.

(43) Voor de "Relations véritables" van Brussel werd op 15 januari 1656 Albert Rubens, secretaris van de Geheime Raad als censor aangesteld (Brussel, Algemeen Rijksarchief, Conseil privé espagnol, doos 1280); voor de "Ghendtsche Posttydinghe" fungeerde een raadsheer van de Raad van Vlaanderen als censor. Dit blijkt uit een brief van het Gentsche stadsmagistraat van 4 juni 1672 (Ibidem, doos 1279); te Brugge werd ca 1672 de censuur op de kranten verzekerd door Jacob Talbout, vader en zoon, die op dat ogenblik griffiers waren van de stadsthesaurie (A. Schouteet: o.c., p. 90$)$.

(44) De drie documenten betreffende deze schorsing berusten op het Algemeer Rijksarchief te Brussel, Conseil privé espagnol, doos 1280. 
in het nummer van 10 november 1681 werd gepubliceerd ${ }^{45}$. Hierin schreef de correspondent dat Engeland zinnens was een troepenmacht naar de Spaanse Nederlanden te verschepen om de aanspraken van Frankrijk op het Land van Aalst en op andere gebieden van de Spaanse Nederlanden te verijdelen; hij handelde verder over de houding van de Verenigde Provintiën in deze aangelegenheid.

Het Spaans centraal bestuur te Brussel nam aanstoot aan dit artikel, blijkbaar omdat het niet dulden kon dat de krant problemen van internationale politiek aanraakte, waarbij Spanje rechtstreeks was betrokken. De krant werd bijgevolg geschorst, doch het bleek achteraf dat de weduwe Graet, die hiervan het slachtoffer werd, geen schuld droeg aan de feiten.

Op 13 november 1681 deelde de Raad van Vlaanderen aan de Spaanse Geheime Raad te Brussel mede dat hij overging tot de bevolen schorsing, maar legde meteen uit hoe het kwam dat het nummer van 10 november $1681 \mathrm{bij}$ vergissing ongecensureerd had kunnen verschijnen. De kopij van de krant had een tijd op de tafel gelegen van de Raadsheer, die belast was met de censuur. Deze was op dat ogenblik echter in beslag genomen door een bepaalde gerechtszaak en had daardoor de censuur van de krant uit het oog verloren. $\mathrm{Na}$ wat verloop van tijd meende echter de griffier dat de censuur was geschied en schonk zonder enige argwaan de kopij weer aan de bediende van de krant, die het handschrift terug was komen afhalen.

In een verzoekschrift aan de Spaanse koning legde weduwe Graet er de nadruk op dat haar persoonlijk geen schuld trof, omdat zij wel degelijk het handschrift van de krant aan de censuur had onderworpen. Zij vroeg begrip voor haar toestand, want de schorsing van de krant leidde tot haar ondergang en die van haar zes kinderen ${ }^{46}$.

Op 3 december 1681 - dus na een schorsing van 20 dagen kwam uit Brussel het bericht dat de Raad van Vlaanderen opnieuw de toelating mocht geven tot herverschijnen van de Gbendtsche Posttydinghe. De Raad had er de weduwe Graet echter op te wijzen dat niet alleen de correspondentie uit Den Haag, maar ook deze uit Keulen, eveneens verschenen in het nummer van 10 november, niet door de beugel kon. De Raadsheer, die met de censuur was belast, zou er voortaan streng op moeten letten dat er in de krant

(45) Dit nummer zelf is in het genoemd dossier aanwezig. Het aangevochten artikel werd gepubliceerd op pag. 3-4.

(46) "n'ayant aultre chose au monde pour gaigner sa vie... elle se trouve obligét a se jecter aux pieds de votre Majesté, avecq six pauvres créatures". 
niets meer zou gepubliceerd worden, wat niet mocht geweten zijn ${ }^{47}$.

Uit de verplichtingen die de gazettier op zich nam, blijkt dus de overwegend negatieve houding, die de overheid tegenover haar gazettiers aan de dag legde. Het zwaartepunt lag op wat zij „niet” mochten doen. De houding van de vorst uit het Ancien Regime ten overstaan van de krant was inderdaad totaal verschillend van deze van de Verlichte Despoot uit de late 18e eeuw of van de totalitaire regimes uit onze eeuw. $\mathrm{Zij}$ zagen in de krant geen politiek propaganda-middel ten voordele van het binnenlands regime. Tot bij de opkomst van de Nieuwe Denkbeelden werden immers de grondvesten van de staat, die berustte op het vorstelijk absolutisme en de positie der bevoorrechte standen, praktisch door niemand aangevochten. De vorst maakte zijn gazettiers dus geen moeilijkheden van het ogenblik af dat zij de vorstelijke belangen, hoofdzakelijk met betrekking tot de internationale verhoudingen, geen schade aanbrachten ${ }^{48}$.

Dit neemt echter niet weg dat de gazettiers zelf gewoonlijk wedijverden om de vorst, aan wie zij hun octrooi dankten, zo aangenaam mogelijk te zijn. De krant, evenals haar onmiddellijke voorloper het vlugschrift, behandelde slechts „overwinningen" van de vorst en zweeg over zijn nederlagen. Reeds Abraham Verhoeven mocht, volgens zijn octrooi van 1620 , Nieuwe Tydinghen brengen over "Victorien, Belegeringhen ende Innemen van Steden", die door Albrecht en Isabella zouden gepleegd worden ${ }^{49}$.

Deze beperking stelde de gazettier soms voor moeilijkheden, inzonderheid in perioden dat de vorst niets dan nederlagen opliep. In een brief aan de Spaanse koning van 1648 schrijft de Antwerpse gazettier Martin Binnart dat hij na het sluiten van de Vrede (van Munster) wel recht heeft op vergoeding vanwege de overheid ; zijn octrooi betrof immers uitsluitend de mededeling van "des prises, assiègements et capitulations des villes, forts et places" en hierover had hij de laatste jaren niet veel kunnen vertellen, omdat het lot

(47) "que rien de soit inseré en icelles gazettes que ce qui peut convenablement estre sceu et publié".

(48) Als de gezusters Johanna en Theresia Graet in oktober 1712, tijdens het Anglo-Bataafs Bewind, last krijgen met de bezettende Engelse mogendheid, laten zij tot hun verdediging gelden dat zij toch geen schade hadden berokkend aan de wettige vorst. $\mathrm{Zij}$ onderstrepen dat in het ghereclameerde atticle van de questieuse Gazette niet het alder minste te bevinden en is, hetgone binderen ofte contrarieren soude den staet, dienst ofte interest van Sijne Keyserlijcke Majesteit, wettighen souvereynen beere deser Nederlanden". Gent, Rijksarchief, Raad van Vlaanderen, Processen, 4e reeks, nrs. 9660-9661.

(49) Tekst van dit octrooi in de nieuwstijding van Abraham Verhoeven van 18 september 1620, getiteld "Cont Verhael hoe dat sijn Excellencie den Marquis Spinola met den Leggher in Pfaltz-Graven Land' ghetrocken is". (pag. 8) - Antwerpen, Plantijnmuseum. 
de wapens van de Spaanse koning de laatste jaren niet gunstig was geweest en bijgevolg niemand gazetten wilde kopen ${ }^{50}$.

De Brusselse gazettier, die steeds het meest in het gevlei van de centrale overheid wenste te staan, heeft van meetafaan de dienende functie van zijn krant willen onderstrepen. Uit het eerste octrooi van Pierre Hugonet, dd. 12 oktober 1649, blijkt reeds dat hij bij zijn aanvraag er de nadruk had op gelegd hoe zijn krant ten goede zou komen aan de reputatie van de Spaanse wapens ${ }^{51}$. Bij de hernieuwing van zijn octrooi op 20 november 1655 wordt dit argument herhaald en tevens onderstreept dat hij zijn kranten uitgaf , pour les opposer aux escrits injurieux des François" ${ }^{52}$. Met deze zg. beledigende Franse kranten was zonder twijfel "La Gazette" van Renaudot bedoeld, die de wapenfeiten van zijn vorst, Spanje's tegenstander, ophemelde.

Tijdens het proces, dat de Spaanse overheid in 1685 tegen de Brusselse gazettier Adriaan Foppens inspande, heeft de advocaatfiscaal de opdracht van de gazettier als volgt omschreven : "Il faut défendre les intérêts de Sa Majesté et détruire les faussetés que les voisins débitent et font glisser dans leurs gazettes. Elle (la gazette) sert pour relever la gloire de la monarchie et les armes de $S_{a}$ Majesté. Elle sert pour publier aux peuples ce qu'on désire qu'ils sachent" 53 .

Naast de dienende functie, die de gazettier t.o.v. de vorst wenst te spelen door diens zegepralen aan zijn onderdanen kenbaar te maken, willen de eerste kranten zich ook reeds kwijten van hun fundamentele opdracht, nl. voldoen aan de natuurlijke weetgierigheid van de lezer. Abraham Verhoeven schreef reeds : „Alsoo daer veel curieuse ende nieuwghierige menschen sijn allen de wereld door..."

In zijn eerste nummer van 27 augustus 1649 zegt de "Courrier Véritable" over zijn eigen opdracht: ,il ne prétend rien plus que de satisfaire à la curiosité des gens de bien", terwijl de gazettier van dezelfde krant bij de aanvraag van zijn eerste octrooi reeds liet gelden "que le publicq en a de la satisfaction".

Toen Adriaan Foppens, na het overlijden van Pierre Hugonet,

(50) „dommages par luy suffert durant l'espace de quelques années que le sort des armes tomba à l'avantage des ennemis, pendant lesquelles personne presageant quasi toujours du mal, n'a voulu achapter des Gazettes". - Brussel, Algemeen Rijksarchief, Conseil privé espagnol, doos 1280.

(51), il ne sera pas inutile à nostre service et à la réputation de nos armes" . Brussel, Ibidem, doos 1279.

(52) Ibidem, doos 1280 .

(53) L. Galesloot: Mémoires secrets d'Adrien Foppens sur le gouvernement et les affaires des Pays-Bas pendant les années 1680-1682. Bull. Com. Roy. Histoire, 4e série, t. IV, 1877, p. 578. 
in 1667 de toelating vroeg om de Relations Véritables te mogen voortzetten, drukte hij erop dat anders het publiek het genoegen zou moeten missen op de hoogte te worden gebracht van wat er in de vreemde koninkrijken geschiedde ${ }^{54}$. Hij voegt er tevens bij dat hij aan de natuurlijke weetgierigheid van het publiek zal kunnen voldoen, want hij beschikt over "une correspondance fort curieuse en divers pays". In zijn nummer van 3 januari 1674 belooft dezelfde gazettier zijn krant te maken ,toujours plus curieuse par les nouvelles qui arrivent incessamment, dont on n'a pas intention de priver le Public",

Als de gezusters Graet zich in oktober 1712 voor de Raad van Vlaanderen moeten verdedigen, omdat zij compromitterend correspondentienieuws uit Engeland in hun Ghendtsche Post-Tydinghen van 20 oktober 1712 publiceerden, halen zij uitdrukkelijk aan, dat zij ,de oncosten van correspondentie supporteren omme aen de curieuse de voldoeninghe te gheven van te sien wat er in andere quartieren passeert"' 55.

Opvallend is dat de ,koopman", naar de traditie van de koopmansbrief, voor de eerste kranten een bijzondere belangstelling aan de dag legde en dat de gazettier zelf het belang van zijn publicatie voor de handelsbedrijvigheid heeft onderstreept. Als Maximiliaan Graet op 17 augustus 1666 een octrooi aanvraagt om te Gent een krant te publiceren. drukt hij erop dat "notabele cooplieden" hierop aandrongen ${ }^{56}$.

\section{De inhoud en opmaak van de kranten}

Een van de meest kenmerkende karaktertrekken van de krant uit het Ancien-Régime is dat zij over de binnenlandse toestanden zeer weinig nieuws brengt, maar volgeschreven wordt met buitenlandse berichtgeving. Dit had voor eerste gevolg dat de tijdgenoot hoofdzakelijk aangewezen was op buitenlandse kranten om over zijn eigen binnenlandse politiek ingelicht te geraken. Hieruit volgde anderzijds dat de overheid vanzelfsprekend zeer wantrouwig stond tegenover de buitenlandse kranten. Niet alleen lokten deze buitenlandse kranten reacties uit bij de Spaanse overheid, maar anderzijds hebben ook onze eigen gazettiers, die overwegend

(54) „le Public alloit estre privé de la satisfaction de scavoir ce qui se passe dans les royaumes et pays éloignez" - Brussel, Algemeen Rijksarchief, Conseil privé espagnol, doos 1280 .

(55) Gent, Rijksarchief, Raad van Vlaanderen, Processen, 4e reeks, nrs 9660-9661.

(56) Brussel, Algemeen Rijksarchief, doos 1279. 
buitenlandse berichten opnamen, bij andere regeringen heel wat reklamaties uitgelokt ${ }^{57}$.

De belangrijkste redacteurs, die in overgrote mate de krant vulden, waren dus de buitenlandse correspondenten. Dit is zo waar dat de Brugse gazettier Nicolaas Breyghel als ondertitel van zijn krant gebruikte: „Inboudt van bysondere Brieven dese Weke te Brugghe aengebracht", en de Brusselse gazettier, Pierre Hugonet, op de titel van zijn krant "Relations Véritables” als ondertitel volgen laat "Extraittes de diverses Lettres et Avis".

In de Spaanse Nederlanden waren de gazetiers uitsluitend op Katholieke correspondenten aangewezen en zij waren dus verplicht vooral een beroep te doen op de postmeesters van de HabsburgSpaanse internationale postdienst ${ }^{58}$. Bij de aanvang van zijn octrooi op 20 mei $1635^{59}$ drukt Martin Binnart er op dat hij over Katholieke correspondenten beschikt te Wenen, Keulen, Hamburg, Frankfurt, Munster en Parijs. Uit zijn rekwest van $1648{ }^{60}$ blijkt uitdrukkelijk dat de meesten van zijn correspondenten inderdaad "maistres de postes" zijn.

De vergoeding, die de gazetiers aan deze correspondenten moesten betalen, behoorde tot hun zwaarste uitgaven. Als Frans Foppens op 28 september $1679^{61}$ overheidsmaatregelen vroeg tegen de onwettige concurrentie van andere Brusselse drukkers, noemt hij na elkaar als voornaamste posten van uitgaven op: „,correspondance, port de lettres, impressions et papiers, outre le grand nombre de Gazettes qu'il est obligé de distribuer gratis".

De opmaak van de krant stelde voor onze gazettiers uit de tijd van de Spaanse overheersing geen prote problemen. Zij hadden helemaal geen redactie-secretaris nodig om uit te maken welk belangrijk politiek of sensatienieuws op een respectabel aantal kolommen op de eerste pagina moest verschijnen. De krant van onze 17e eeuwse gazettiers verscheen meestal op 2 of 4 pagina's, elk van één of twee kolommen. Niet het belangrijkste nieuws werd eerst geplaatst, maar wel het oudste nieuws, dat meteen van de verst-afgelegen plaats herkomstig was. Hierop volgden nagenoeg in volgorde van afstand en ook met minder verouderde data de

(57) Wij wijden hierover niet verder uit. - Cfr. Brussel, Algemeen Rijksarchief, Conseil d'Etat, bundel 1846.

(58) Naast de zg. "Bucbbändlerzeitungen”, die door individuele boekhandelaars in Duitsland werden uitgegeven en dikwijls protestant waren, waren de "Postzeitungen", uitgegeven door ambtenaren, verbonden aan de internationale post van de Tassis, katholieke kranten. Het is in de kringen van deze postmeesters of ambtenaren van de internationale post dat de Spaanse gazettiers hun correspondenten moesten zoeken.

(59) Brussel, Algemeen Rijksarchief, Conseil des Finances, bundel 265.

(60) Ibidem, Conseil privé espagnol, doos 1280.

(61) Ibidem, doos 1279 . 
andere berichten en de krant sloot meestal af met berichten uit het binnenland, die dan ook het dichtst aansloten met de datum waarop de krant van de pers kwam.

Deze korte mededeling over onze „Eerste gazettiers en hun kranten in de Spaanse Nederlanden" had niet de bedoeling het onderwerp volledig te behandelen. Wij lichtten slechts enkele hoofdzaken uit een meer uitgebreid dossier, dat wij nog hopen te kunnen aanvullen met het oog op een omvangrijker publikatie ${ }^{62}$.

(62) Dit is de tekst van de voordracht, gehouden op de Plenaire Vergadering van de Koninklijke Zuidnederlandse Maatschappij voor Taal- en Letterkunde en Geschiedenis op zondag, 15 maart 1964. 



\title{
VVekelijcke Tijdinghe- Nwm
}

\author{
I T I I I N: \\ VVt Roomen 26.Mey. $1629^{\circ}$
}

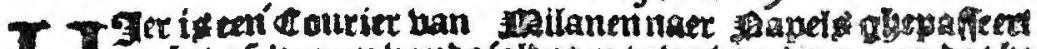

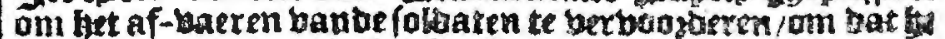

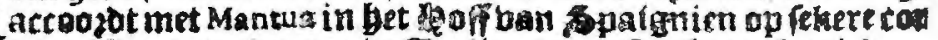

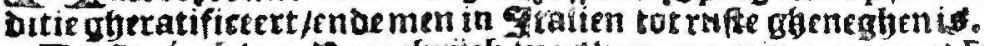

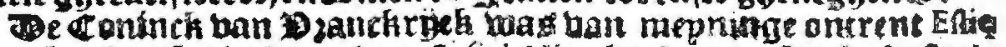
uriche platife niet beere ban sulo is ligghemberen ftetch eafteli

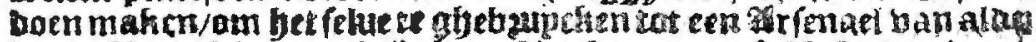

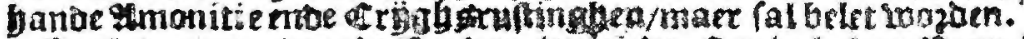

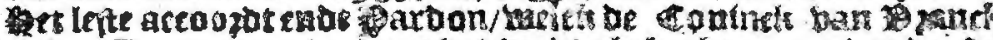

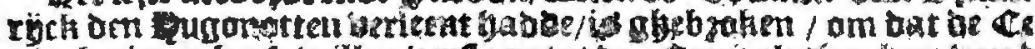

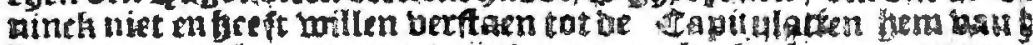

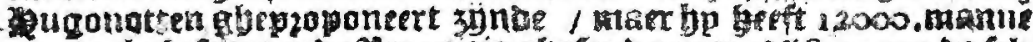

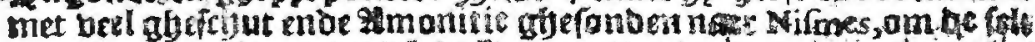

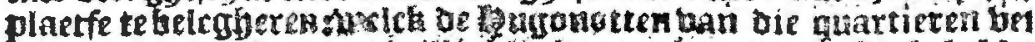

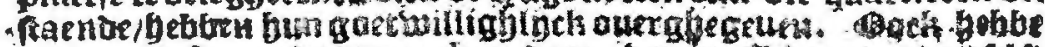

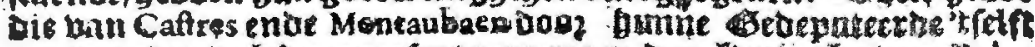
amben coninck benpzeienter minaer on

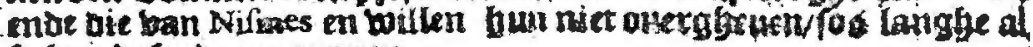
sp gun Dafeneren somnen.

$$
\text { Nocb votroopen: 2. Aunij. }
$$

Met renen extraozoinari bau Milanem berfaet meri/ bàt be

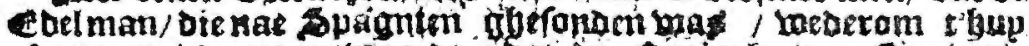

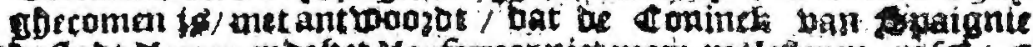
be ftadt Mantua enoe bet Monferraer niet megr moleftecm nifal/

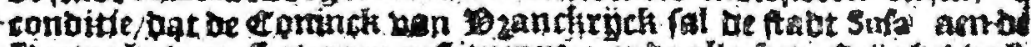

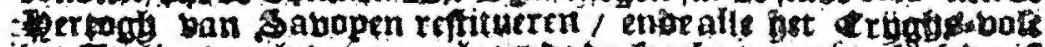

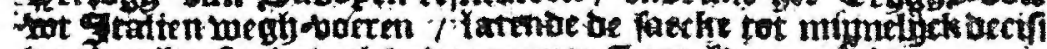

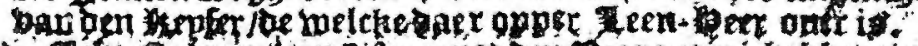
- Irgt ajepen ban Bifertamet ogp

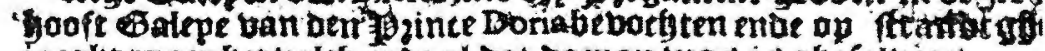

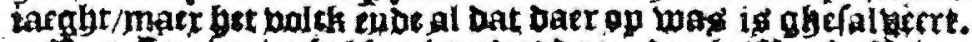

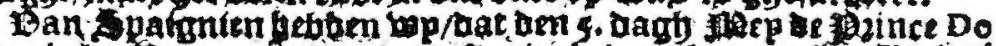

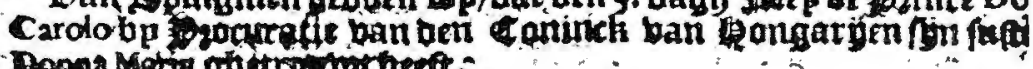

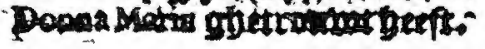

Pl. 1. - Dit is nr. 1 van de "Wekelijcke Tijdinghe", de eerste werkelijke krant door Abraham Verhoeven te Antwerpen uitgegeven. Het nummer werd gepubliceerd op 27 juni 1629 en vangt aan met een bericht uit Rome, dat een goede maand oud was (Brussel, Koninklijke Bibliotheek, fonds „Kostbare Werken”). 


\section{Courante uyt Duyt fchandt, \& 8 . 1632 . .}

Wt Triervan den 25, Februarij.

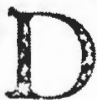
Ëll Conturli ban Deanriatigle me Leat cindmist Ruchelacu enoe bet gle

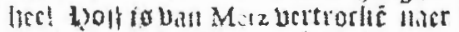

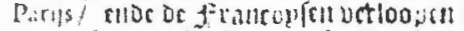

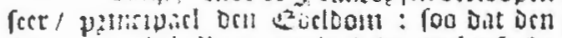

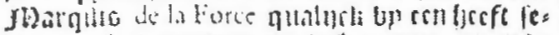
bent dupfont manten of befe quatte:en / oe

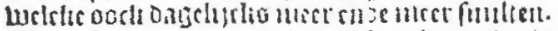

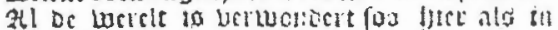

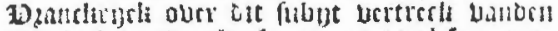

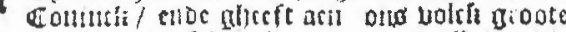

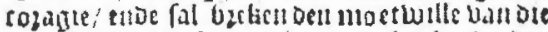

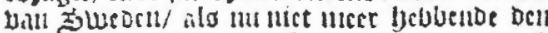

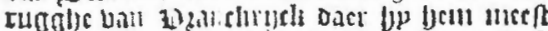
op betroiludor. friclifpacelit feer diffecentelure

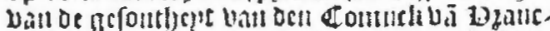

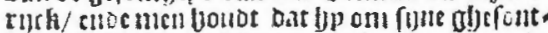

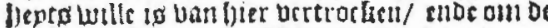
tronbelen Die bu vecl! bimuch parijo choe an. Dere quartecten bes Layrtiog. Den Cardilacl

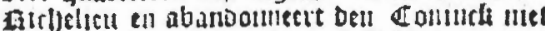
muta yp wzesf bell woet aljeliegt to wo ben Dooz ven Zeglelbetwacroer cnde andere. Een

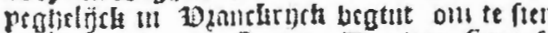

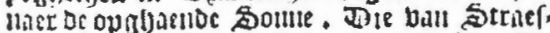
Lozglj feluben phat of gljebueprert aen oen to.

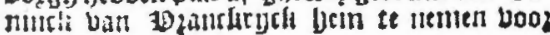
pzoitterue.

we Weenen van den xo. Februarij.

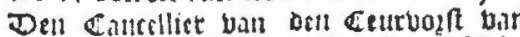

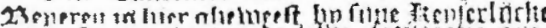

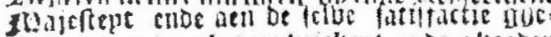

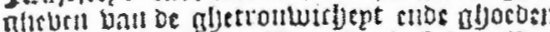
wullertug uterferd. Bell commb vau $\mathbf{p o n}$ Im befe Doen lesliten tot bienfe uan ben licp.

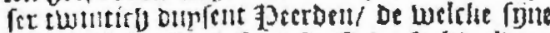

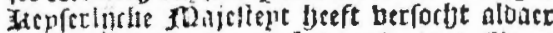

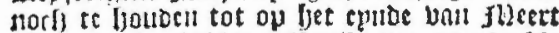
oft tot bee breginlel ban abail/ Laantere oe fel.

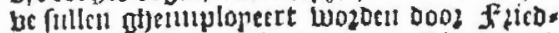

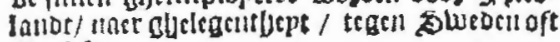
Durluett.

Wt Ceulenvan den 23. Februatij.

Don sonmel van Blococn/beft liset nllect ach De pentucell ban oe Catfolitgue zige/

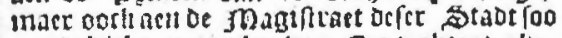
curcelijclie artirulen van neutralitept alje. pzoponerer bat alle oe baffelen ente sote.

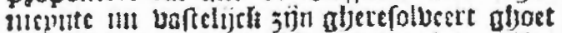
endoe blact tegefull dent felben te wagben. Tot welefarn epnoe Dent efacot alfice becft op. nbenomen over be negben Dunfent manten/ the berforfit acel ot Beremifme Gnfante tot 23 uffel/ oat fo fouben willent feptident renent 3iLgtier oltber de beftell ball ef erilen foo verce Den Conimet ban foweden foube begbranen nederwasted ben higint af te romen. ende onder andere foo is den Sormuts biti Saint

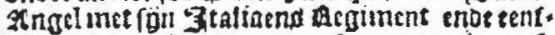
ole andere oroupen aengteromen op onfe

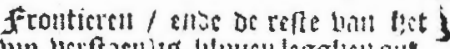

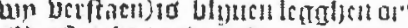

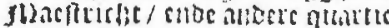

We Amicns van den 24.1

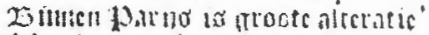

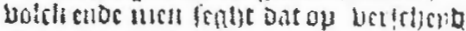

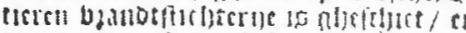

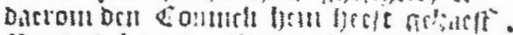

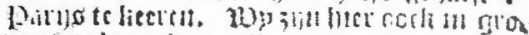

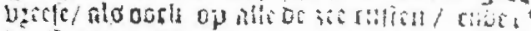

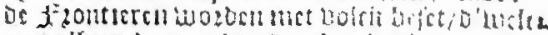

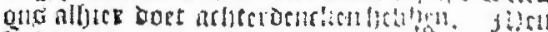

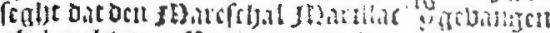

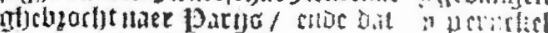

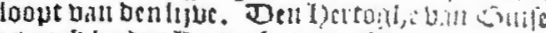

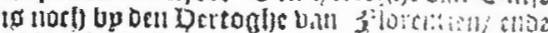

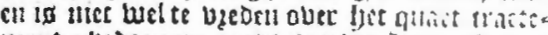

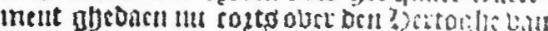

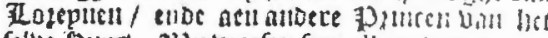

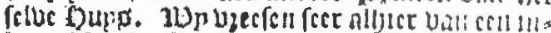
handerbe soplonde / te turet on onelsin corls

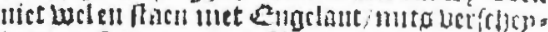

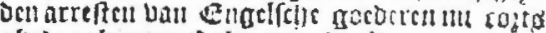
gbeoacubinich lioljanten entic tocro.

Wt Weenen van den 2 Februtrij.

Den Dertoglye van frieslantot lerft nit co or becuent onttent 70. Aitginfuten / chis: lis

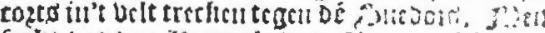

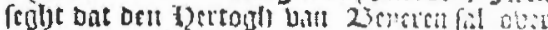

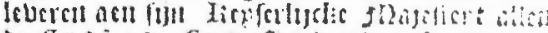

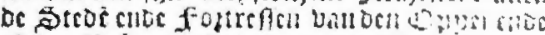

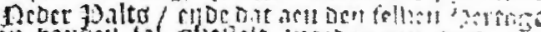

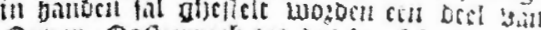

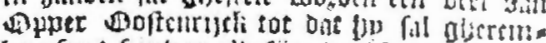
bourfect findait alle fijuc berfolocen ycmin. gijen.

Daet cout oagdelijelig groote menigte vat boldt alder actl foo upet Polen, Hongarye Croz. tien, Sticrmatck, chbe antocre Zlanden / nuloto get goet tractement belsh fp f f ban firicolandt.

Wt Bruffil van den 6. Meert.

Den Marquis de Santa Cruz if Inet Enacf Ian van Naftau, Don Carlos Coloma, Fraj Lcho Brancatio culac nicer antoere yzincipalr yerfoone

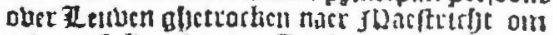

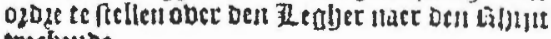
trerticuide.

(1) nde alfoo men berfart bat ion Cominge

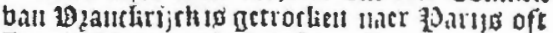
Fontancbleau, clloc Dat ftyc ceroupell oy de

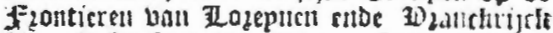
[1]n aluefmolen op ontrent fisen onplent Inamen / dat ooch ber soluede allen fin

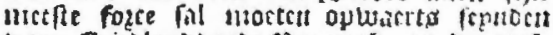
tegen Fuicoland cude Papunnliegra; Dat oota Die bant of enten alienoes!) ban volefs / Bmomtic

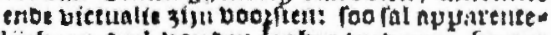
livtheen Detl van bent legber weoctom ferret nacr 23 gabanot oft eloen naer De occurrentis ban faechen / ce meer om bat men Leffact Dat

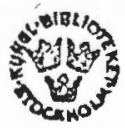

Pl. 2. - Het eerste bewaarde nummer van de "Courante”, de tweede krant van Abraham Verhoeven, uitgegeven ,inde Gulde Handt op de Lombaerde vcste" te Antwerpen, dateert van 10 maart 1632 (Stockholm, Koninklijke Bibliotheek). 


\section{Extraordinaris Poft-tijdinghen des Iacrs $1635 \circ$ den 8. Iunij. No.14.}

Wr Napels raded 10, Mey.

Ifen Dicetop allitict firefe nof bite.

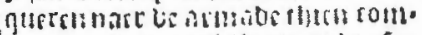
paglarn boetearlallen/on be 60 .

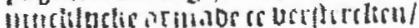

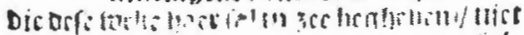

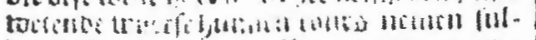

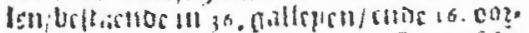

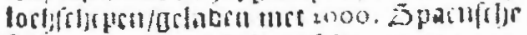

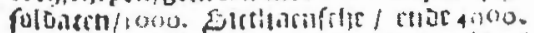

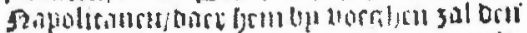

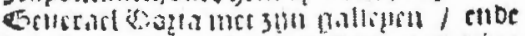

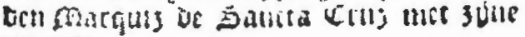
Btmaloe.

We Straesborgh den i4. Mey.

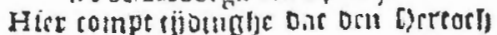

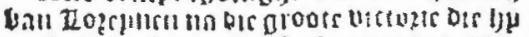

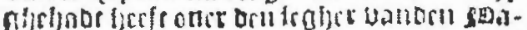

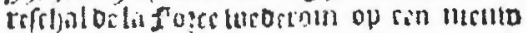

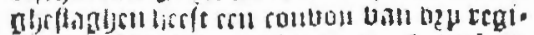

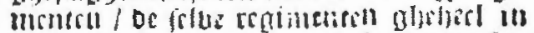
rotare gljeflingien $/$ bet glate buter ba

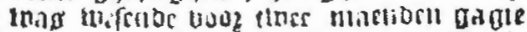
voopt forme Iraberior vives enoe alle bue ammintele becomets.

Wt l uj ck vanden :. Tunij.

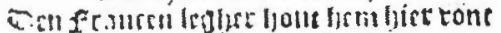

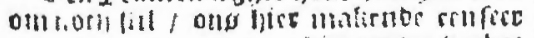

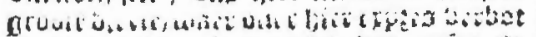

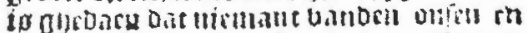
imirly pacil fortelen lint Ifglice. Comin

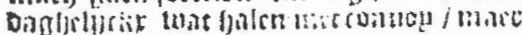

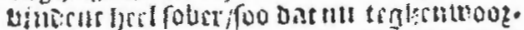

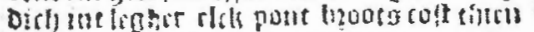

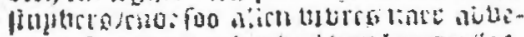

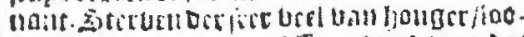

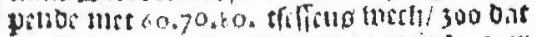

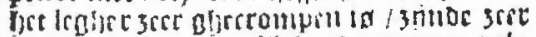

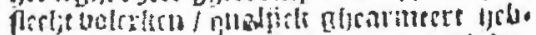

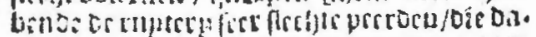

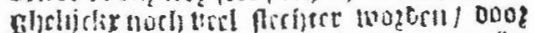

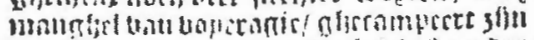

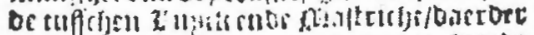

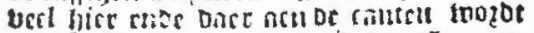

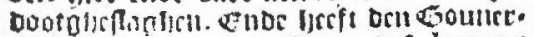
netr ball samenen befe arn orfe loopers oure be soon. cnoc pterlürlic jonocroch

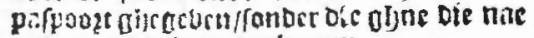
amocre quarticein uecloopers.

Wh Gulich vanden felven ditto.

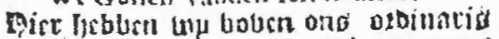
norifioan norly 1000 . Inaturtl ingectegen/ foo ont tny liumict mese en bzerfot. Ca.

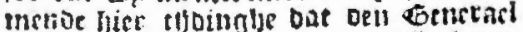

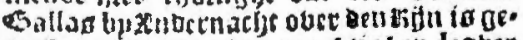
pafiect wiet crmmires mactigben legber te boet ento re percos.
We Maxeyck met de lacte bricuen.

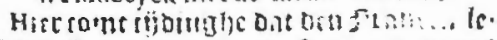

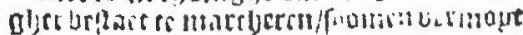

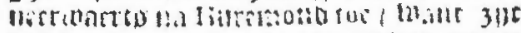

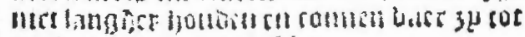

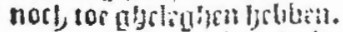

We Luxcuborsh don 2. Innit.

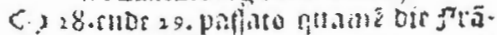

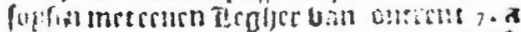

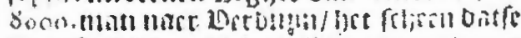

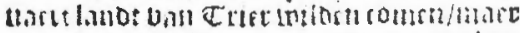

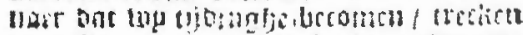

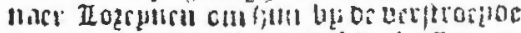

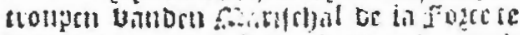

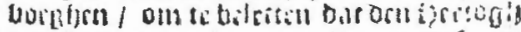

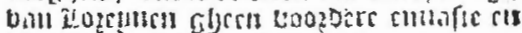

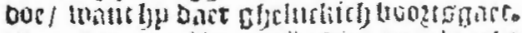

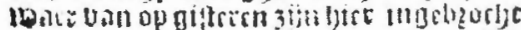

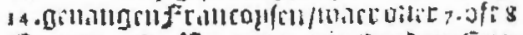

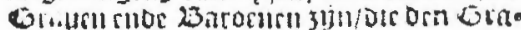

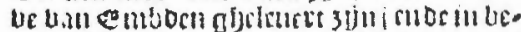
mali allfe aljenomen / bis tarlfullitu te pala

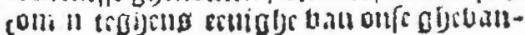
afjel ill.

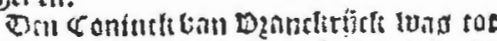

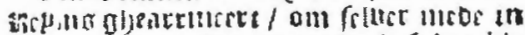

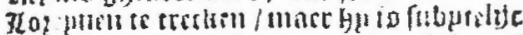

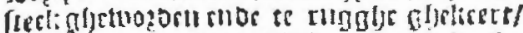
men frut meorrom eculghe urtgonomolie

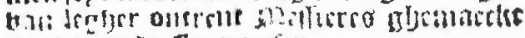

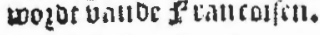

We Duyukereken vanden ; Iunii.

Dic 2 2. Gonince rencpen bic oulanet

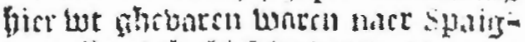
mat jỏn filicluchith lacortou? grea::icm mede bicughruise cen grogt orel uau Spaigniardoen fracp boleli thoc zoo. enfirnmet fruer / lliets boop feftectij-

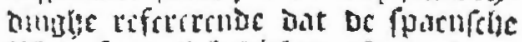

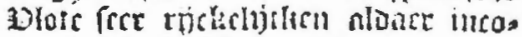
ma bonf gibefolut op 17 . mllocnen

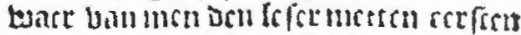
allen particularitept fal laten locici.

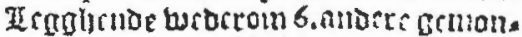

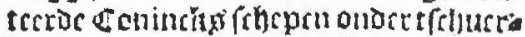
Kentammet dic aldecerfte orcafe lat te batch / buct nacr fepentai oatfe bots sbetrarrtistin.

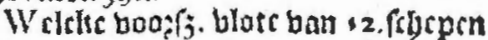
bogbe plycuaclif van 14. Stactfols Co:loglafchepin/cubr 5 . oft 6. Iran, te oin dic te nttacquerch/ macr fiende oc fello foo nhemantert Drforn tiet iacn boost folnch

Pl. 3. - Het eerste bewaarde nummer (nr. 14) van de krant van Willem Veràussen, de „Extraordinaris Post-tijdinghen”, uitgegeven te Antwerpen „op ons lief Vrouwen kerckhof, inde X Geboden", dateert van 8 juni 1635 (Stockholm, Koninklijke Bibliotheek). 


\section{Anno 1637. Den ordinariffen Poftilioen. Num.16.}

\author{
Hoogh-Duytchlandt
}

Vyelufpruek, den 26. Mecrs.

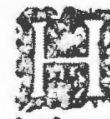

ger mozoon boos ortoll omoe Hectrib-pertoginan geoote yt reserfyapeses gujemnecte! oin cen luel magnifinus totbaett te

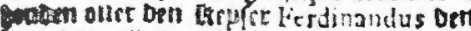

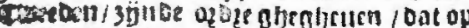
ten bagh / als de lotbarrt fat glietjouben atom / alle bacre onorrfach fullen in

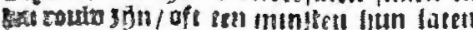

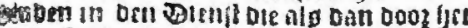
chlete canot fal abebaen toozocn.

Oe sectfily-gertogunne fouor bieuen

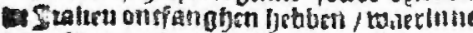

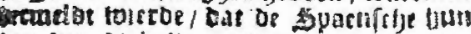
van bet Valtelin gaocen meeter alje.

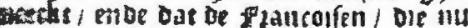
(x) wepntgh gijetaogon siln doog flecfer

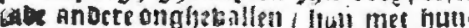

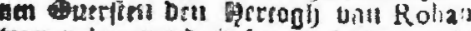

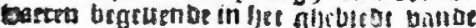
serniatuen. Penoe 1 211 buers/ Dat oc Egre booficnighruo: ban orll vureleben Erefie coll bp ifjoes berfich baobe, met

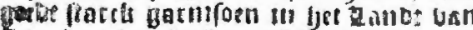

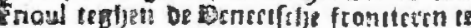

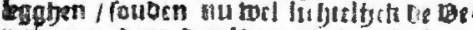
weasamen bool ben bertagl ban Rohan, guenfups tut ben naem ban Deanclityik

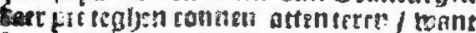
aber alidie een bendoence ooce cp yith zxajhetive.

Buicuen ban Milanen Ugothen / Lat be artin Qbedeputcros ban brnje! bes cetepljootne ban Milanen tor orn na:m

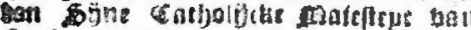
Gadguten / om nare Ceulen ap de Bre bene peartalie ic topfen / tertrocisn toae

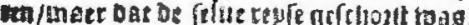

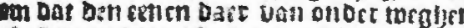

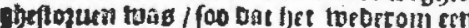

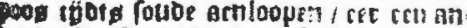
in m placefe geozuennerti foud twozosn.

$$
\text { Vyt Lypzigh, din 4. Ap:il. }
$$

Se somoltye bicioen bun noty be

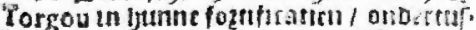

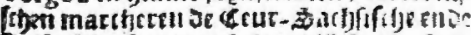

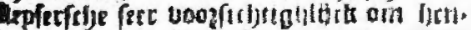

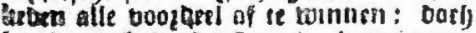

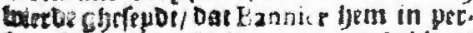
focn foube naer Hal gleceflerst liebben/ om bu rotg / fil olen fönen Irgure foude de atberlagize juebuen / wat ben flof te toe

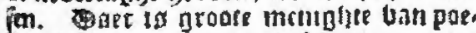

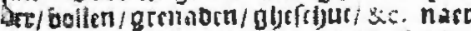

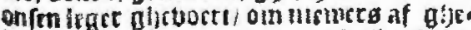
bete of jobuen / rnbe ouit al zön com. athariffil tor/on bismontese of te coa

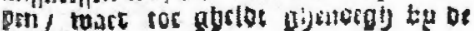
Wertsig.
Vye Vialsershaufen, dene. Alrat.

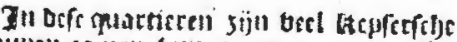
troupen coinen buth quirter $11 \mathrm{emen} /$ ruo oat lyet byoobt fect féfaces ata crivoljen tes toant of borren oure al merliniderl ocr. loopen / entie hiet en rullen vertwicliten oen otstelalt vande fulosera / oljeproefe

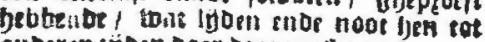
allbeten Ig Den Dape Dooz onsthaen io.

eoc Ordortf, Armilatt, limenav, inde Toe boozs itae oen saslilroom opligite

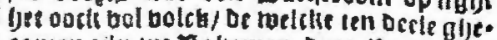

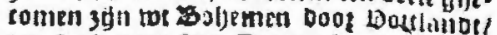
ten beele ouet of il Buringleer-tnaloe toe

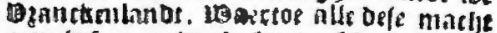

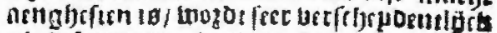

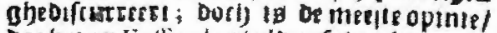
Das jeet op Erftorite gijeloen fal / alwate or

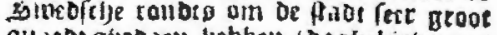

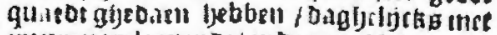
rouprn tailoopende / en be maer V V ninaer. Gothe, pllde Naunber ho jel lanot of.

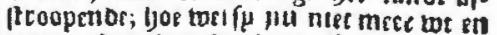

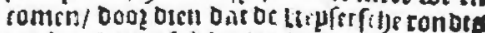

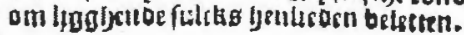

$$
\text { Vyt Futla, den 6. April. }
$$

maenangl) Irfitebn sún biec entrem

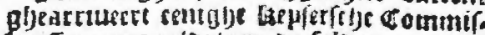

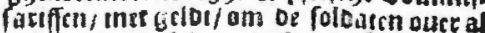

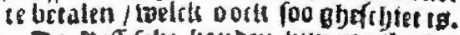

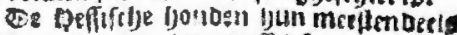
in ee qilarticral vall Cascl; foomea fegisei

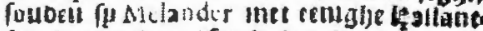

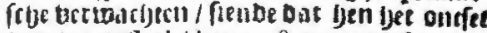

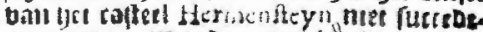

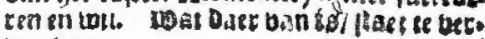
warblet.

\section{Nederlande.}

$$
\text { Vyt Dien, dea aj, April. }
$$

Top an areen wirt beter / ofs byer in brfe

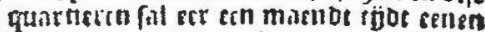
leg!er vall 20000 . oft merc mannen bp

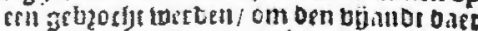
mede ach ic toiken/De torl, be foo berfiffy.

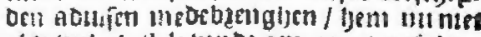

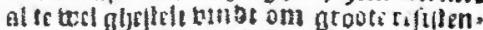
ste te Dotil. Cot fulcken cuntos to alfute alrec oe cen groote meniojice ban aloct.

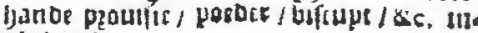
glictazorifl.

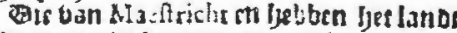
reorecenglys bagyen mei miloopen elloe (troopern int hilligl gljaballen; foo men

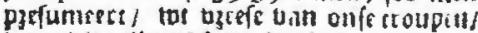

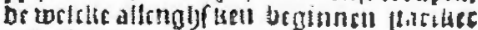
and ftarefier le unozarn.

Er Gollanores ljaoden betnomen/Dat

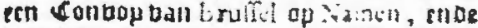
ban baer op Lutwibug gaen fonbel

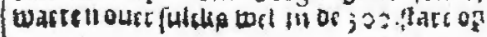

Pl. 4. - Het eerste bewaarde nummer (nr. 16) van de krant van Martin Binnart „Den ordinarissen Postilioen", uitgegeven te Antwerpen ,in de Bonte Koey", dateert van 21 april 1635 (Brugge, Stadsbibliotheek, samengebonden met 83 nummers van de krant van Nicolaas Breyghel) 


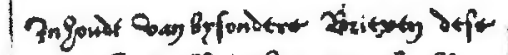

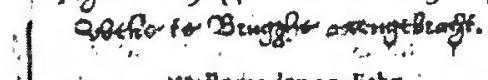

Wr Rone den sx. Febr.

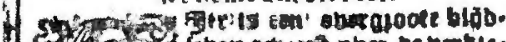

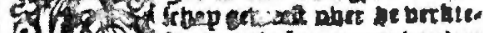

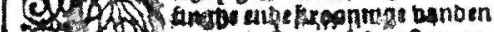
To 1 (x)

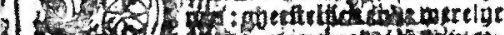

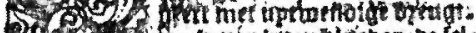

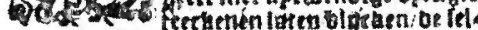

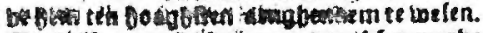

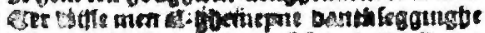
aratsare brife nat gen lof fangh. Te Deum Ladamus, gebtentarer legfell woejaigh gbe. best bueren fwiaticb darbiualen: alle de intes concaroinasl ban sapopen ten mib-

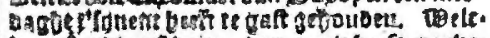

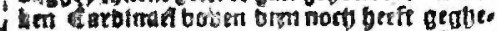

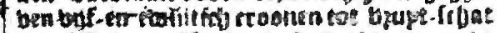

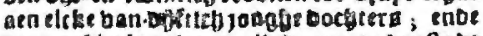

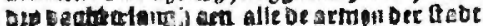
Gomea En initi 600E-Bheberlio toegeftiert.

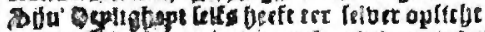

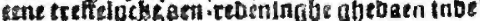
boolurntindet vergaberinghe cer alorrup?-

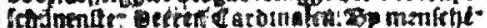

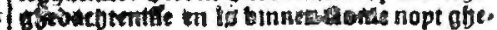

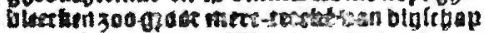
enmeghenacahter. W'so ben Gertooh tart a at sun-laken epobelets verebelectien bed mex den Conting ven hipanjea; getfe oun aug hun ooch weoer - oftalleben be ofe

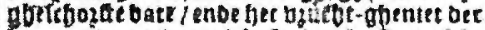
Len-goetorren/be melike fp banbr ctoonictie

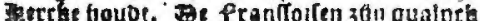

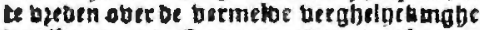
ban germtu enbes panjen, ende en tweté boost siet metr ban twat bout yolen mahen / om be

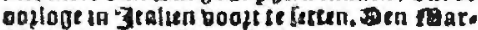
Itbalch ban efrebt berifdetmen oberfulcr na ben onnab celonben te beblon om nteute

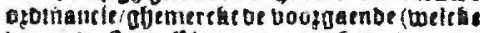
goas / be Rabt polacence te ontretten) mer oe biede-maechnge banben booznoernoen per. toght te bergerfs is. Buber be franfehen is graot guebzech van leeftoghtm : vele beclets. ber oberfuliks berlooplen / ende nemery orm bp be spaenflice. We Winen den 23 . ditro.

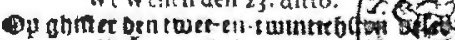

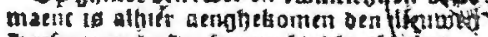

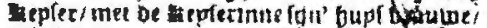
acbe baglien naes bet obeclioen fting wates

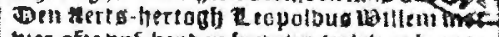
bier ofte bnf benoen henghs-bolet is jem te goemaete ghetrocken. mic ben Isliepe gaenbe

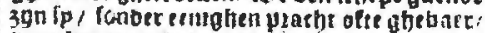
booz het upterlie ban bethabt in cet sof abe: sominer. Befentil alteit a voist ocur ig alfier ghemerft eene g:oote filis / elloe in aller aen. fklit cottwe enbe bzorf firpe: baer inas cen oo pentace ucrboot ghebaril / bat niemant bem en folloe berbaot Deren/ eenigh lpul/oely/ ofte gbenoegne te be ozoben / tor baeser anber of. bye loube balghen. Xseg odectroen seplers telament frght men gropent te wefen / til bet

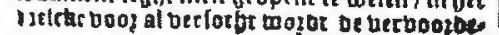

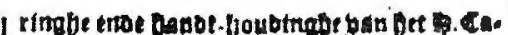

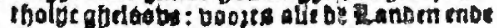

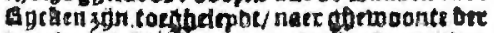

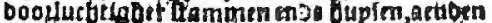

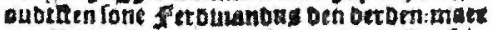

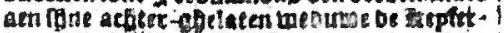
Inne is belf th treffelort ense serlic sion.

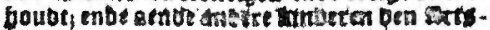
bectogt enos sierts -jer loopents is gorlacen het oberfebos. Ben fongben lepter fal iun

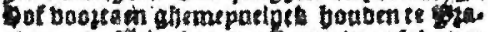
Gle / enoe finkn bjorbrt leovolous fal othe

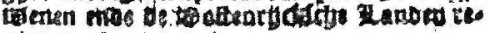
gieren.

Ws Wursbourg dep 28 . ditto.

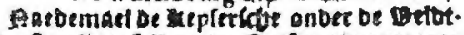
overRen gas afelot enoe botfen / Ingenomen

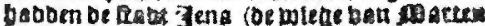
Zuther) foa gebben lp be stoeforche Eroge-

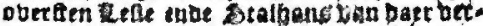
Dezeben : Us toelthe als gbeliagen blutótmbertwefe fitb nas aumbourgt lpocombe/30n op ben achiftenten enoe wegbentótenfen orfix maens bp onfet upterje onber begle actitet-

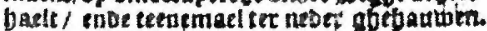
Droertutecen beeft ber \$arenaren opper.

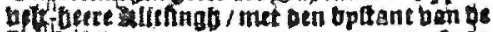

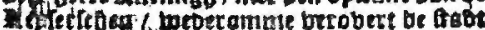

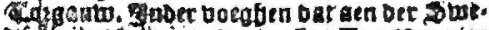

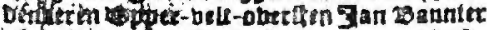
acmetiotm xon alle taentorn om te ontolurb. tofe oie wa m

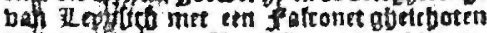

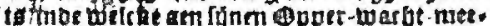
fter oock een been afghefchoten to ; heeft firf etontwel tart fonm bepz-legljex bef"ieben na zut3en / ende ftaet oase frn boogbate giscluch te moeten toggen; baer ban top t'alst are oe upetiomlte sermaebeen.

Wr Meins den 26. dirto

Boer fommighe bagben in ben ato.mee ter a grolant mes fonec roaten gbeballen tribe

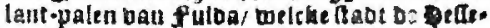

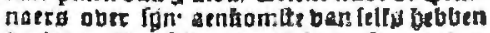
berlacen. Sen felpen beco is Inafegarm ben fo arck ulatue ban ogana/met acbe taegtmen. ten oologhs-bole be wetetie men frbigft bat

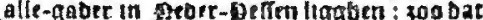

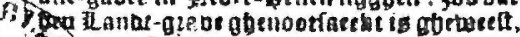
'tan' upt gijefichee frrigha hoopen webrom lif og bafte ende atertie vlartin te legaben.

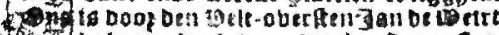
Keing be bope gbegbeben. oat bet permelte

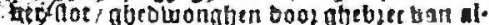
I irpande noodotufe / haet fal mofen oberhonen : waet natop mbe alle onle ghebuerm

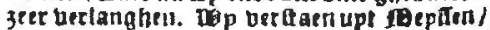
dat ghefjeel Baren lanbi noen geonot broos. ben is ente berworft ; hebbenbe cen laetden boo een rechebritoigh ooloeel gobes oot - obelmaecst be bzucturen ber ketrerge i bie upt

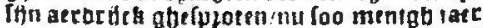
aen gantfele bettenboul boben maten btter etroe coobelnet zin ghetaet

$$
\text { Wr Answerpen din 21. Marru. }
$$

3ongbfe buteven banben frantfozticben pol-melter bouben in, bar Gan sannies notb tat ghemen tarnien Gagb en is gheho* men / bant bp tcacbs bea felocn gbebueriget

PI. 5. - Het eerste bewaarde nummer (nr. 12) van de krant van Nicolaas Breyghel, "Nieuwe Tydinghen uyt verscheyde ghewesten", uitgegeven te Brugge ,inde PhilipsStocstrate aen S. Donaes", dateert van 14 maart 1637 (Brugge, Stadsbibliotheek). 


\title{
, \\ sitest. 2. \\ LeCourierVeritable \\ DES PA Y S B A S.
}

\author{
De Tournayle 3 r. Aoust.
}

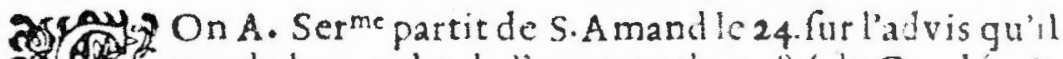
eut de la marche de l'enneny du colté de Condé, ix à unchelie en deça fe logea certe nuit lá co campague avec l'arméc. Le lendemain 25 . fadite A. arriva en cette Ville; d'où par fa vigilance ordinaire elle envoya promptement les ordres necerfares pour la feureré des places par delà l'Efcaut, aufquelles le pofte de Condé fembloit donner quelque accés à l'ennemy : Cependant toutel'armée eft difperiće à S. Amand, Quefnoy, S. Gillain, Athe, \& Enghien, \& aux environs de Bruxelles, \& decette ville.

\section{DeVallenciennes le 31 . Aoust.}

D Epuis que l'ennemy a occupé le porte de Condé, il ne travalle qu'à le fortitier, \& le munir de toutcs lortes de pro. vifoons. Et cependant il va courant \& fourrageant aux cavirons avec fes violences ordinaires, mais fans beaucoup s'efloigner.

On nous vient de dire que le Colonel les Croites a efté tué par la garnifon cunemie, quieftoit dansle chiftcau de bofu, \& que fa mort a efté vengce par celle denviron foo. fancallins de cettegarrion, \& par la fuitte de quelque Cavallerie qui eftoit reftée dans!e Chafteau, gus farce moyenaefté abandonnné delennemy.

Pl. 6. -- Het eerste nummer van de krant van Pierre Hugonet, ,Le Courier Veritable des Pays-Bas", uitgegeven te Brussel en gedrukt bij Jan Mommaert, dateert van 28 augustus 1649. Wij publiceren nr. 2, omdat de krant sedertdien haar definitief uitzicht kreeg (Brussel, Koninklijke Bibliotheek, fonds „Kostbare Werken”). 


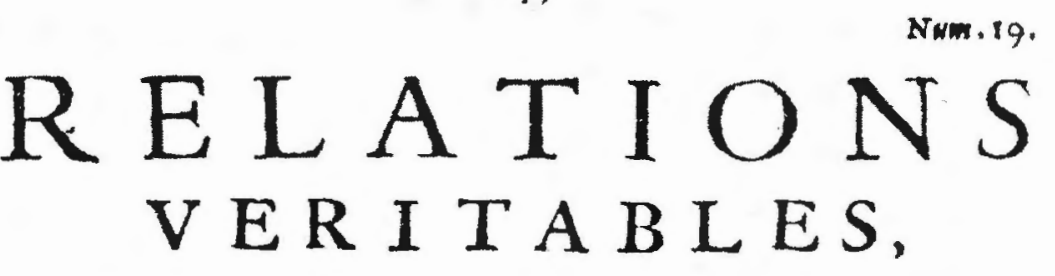

EXTRAITTES DE DIVERSES

Lettres \& Advis.

\author{
Dx 14. May i650. à Bruxelles. \\ L'Imprimeur aux Leetcurs.
}

\begin{abstract}
Es Relations quittent le titre de couricr qu' elles a poient ufurpé fort innocem-

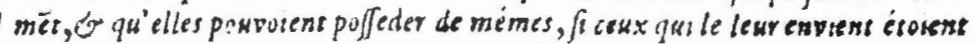
moins erisiques; $N^{2}$ atrendez pas. Lecleurs, que l'on vou donne wides raifons de ce

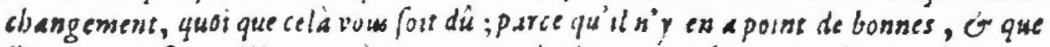
l'Auteur n'eft pas a bsmeut à vous apprendre les masivales qua ly obligeat; sçabbez fontenarat, que la qualité de verusables, eff celle gue ces Relations ne sedgoms jamair,

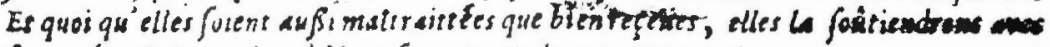
fermeté ensiloniems qu illeur fera permu de vous entretenir.
\end{abstract}

\title{
De Naples le 9. Abril. 1650.
}

T 'Elû du Peuple a ordre duViceroi de faire faire gráde quantité de bifcuit blanc, dút il en ct deja arrive de Palerme un varfifau tout chargé pour le jervice de la flotte, Aujourdui on a mis cn mer une nouvelle galere, \& on elpere qu'au plûtôt on en met tra cricor une autre,Cepandant on cómence d'embarquer l'artillerie avec tout fon train fur les vaiffeaux qui font déja prets. Dom Iean Battifie de Montfort Prelident de Trani a été continne par le Roi pour 3 .ans au commandement des anmes de cette Province li. On a aufi nouvellesque ra Mée. a dedaré Grand d’Épagne Dom Bertram de Guevarra Frerc du Viceroi, Et Dom Femando de Moroia Regent

$$
\text { O o }
$$




\section{GHENDTSCHE POST.TYDINGHEN}

\section{EDonderoagh oen 8. September 1007 N. 69;}

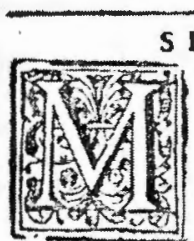

$S P A G N \perp E N$. Sorto 13. Cugfe. Onfe Miri. fters finn particulierlugek gheoccupett om by eea te vergaderen gruote Sommea van Penningen. tet onderboudt ander Ourlogh die wy fija bebtende mer $V$ rancrigk : daer van mer dekn ordinairen Poft van Spagnien Syoe Excellentie dea Marquis de Caftelrodrigo voor: O duylene Croogen Remifenghefonden fija; en worden binnen Madrid noch 1. Milliamen ghecontradect. Op lle de Perden en Kocten is heut Sauncn doot et. acn Tas gheftelt, om alloo te berer Gelt - nuddelen op te brengtien. Soo de Franlche gheen vourace Progerfen en doca, hopen wy her roccummends Jaer warberer in Potues te wefen, om de fulve te connen refifteren; Dserentufhinen laetmen bier viet naer eenighe midetefente forsken; op dat al. Ie moche by gateyt worden. Den Herrogh vin Veraguas heeft irdre ghekreghen, oin hem, net Gre Vlore in Zeces begheven. Deledagen beet deo Grave van Caltrilio permithe ghevracthe, vande Conunghinne Regente, om af -ttant te troghea doen van fjo Preficentichap van Cafullien, overmits fijnen grooten Duferdom, ende indifpo. ficic; maerhet felve ss hem biet ghecunfemecrt, alrooin defe Codjunetic van cijr, mes fijnet Ract verernoch wilt dienen. $V_{2 n}$ fidorr dne de Schepen des Los Alug ues feor arer by waren, Gode geVe das jo beloudea Haven mugten commea.

$$
\text { I T A L IE N. }
$$

Genua 6 dito. Get folions da: be wofllttrets

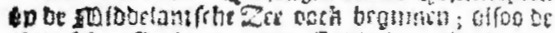

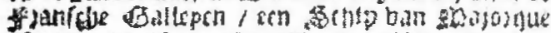

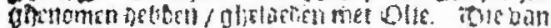

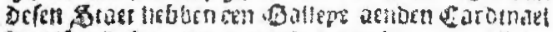

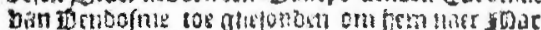

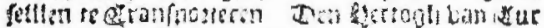

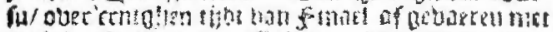

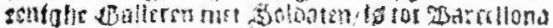

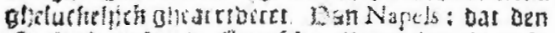

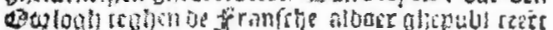

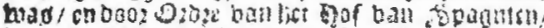

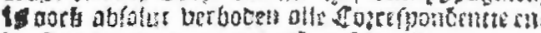

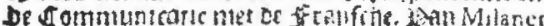

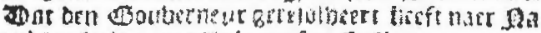

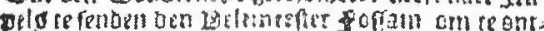
fangorn or sonme uan 150 . Dugfent erooney/

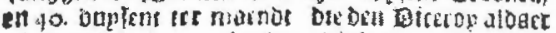

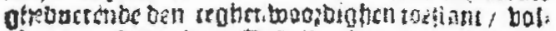

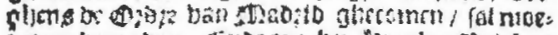

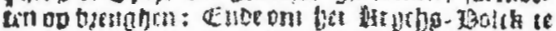

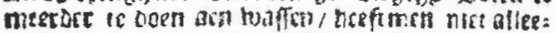

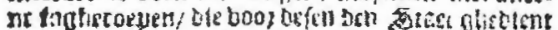

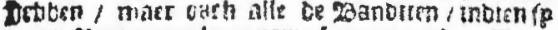

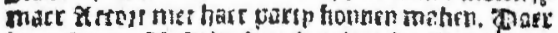

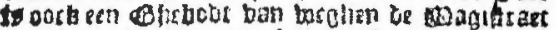

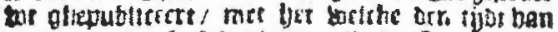
cenc syamor ahefeit is/ aen all: bic

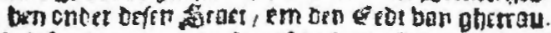

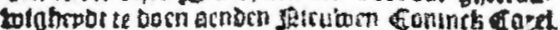

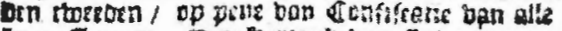

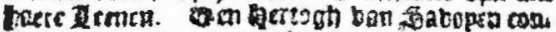

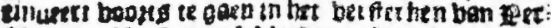

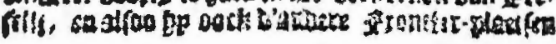

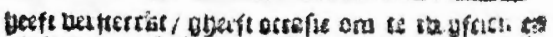

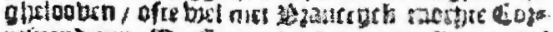

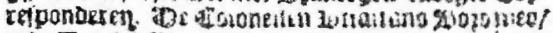

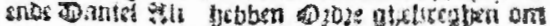

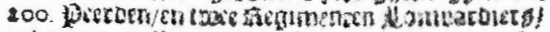

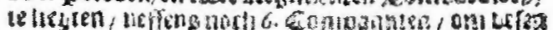

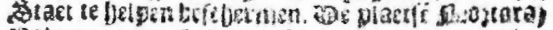

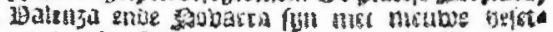

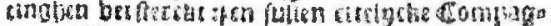

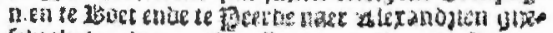

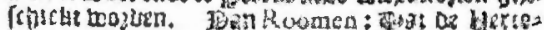

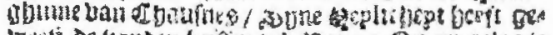

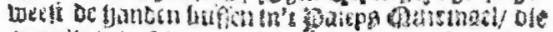

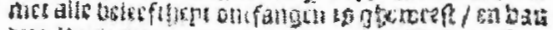

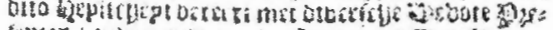

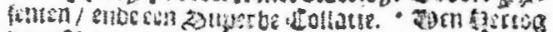

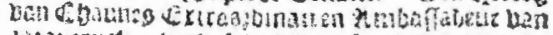

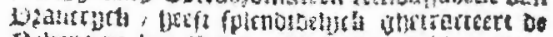

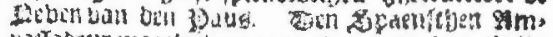

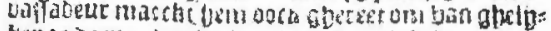

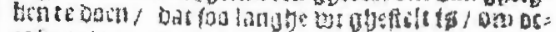

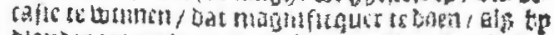

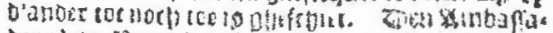

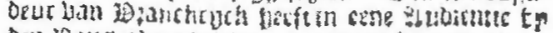

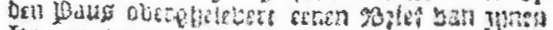

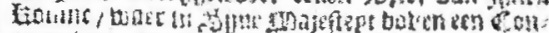

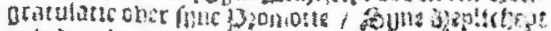

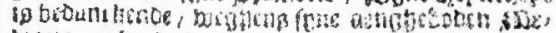

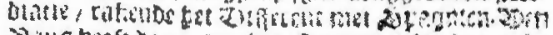

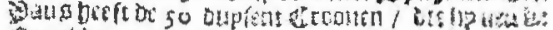

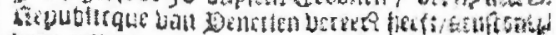

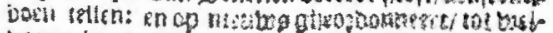

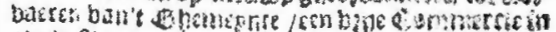

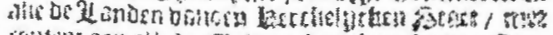

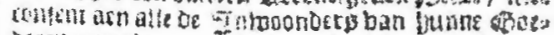

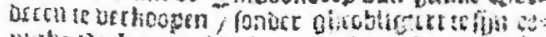

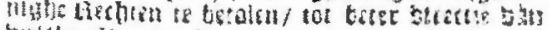

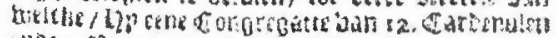

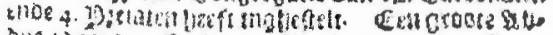

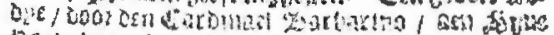

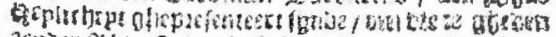

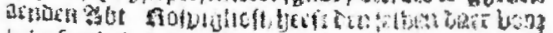

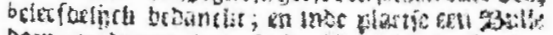

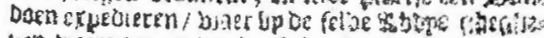

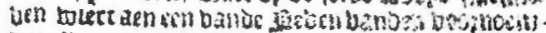

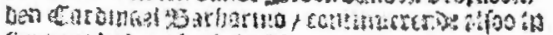

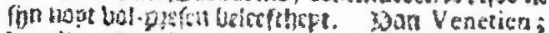

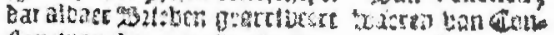

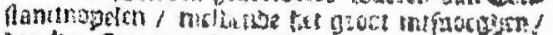

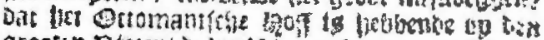

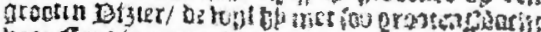

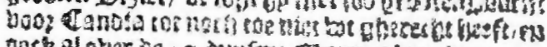

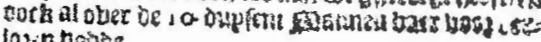
logintoobse,

DUYTSLANDT, POLEN.

Petran 20. Duags Den Baron van Minäisgrats is van wezhea Syre Keyferlijcke Mn;efieyt ghefcaden neer her Hoff vap Ztieden, on aldaeeenighe Saken vaa gruotelmporkstie te aegotit ren. Gifteren q̧uam hies Tyouinghe, ost de sa duyfent Florined aner Tyrol ghefonden torbet lingbe rande Soldsice, onder wegh eenglestet fin ghewsef, door ceren Graef Cuczia met axh fit andere Perfoo aca, daer yabeen Kauter adnet 8 ,

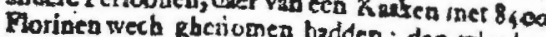

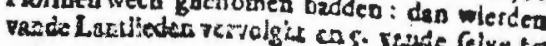

Pl. 8. - Nummer 69 (8 september 1667) van de "Ghendtsche Post-tydinghen" is het eerste bewaarde nummer van de krant van de Gentse gazettier Maximiliaan Graet. Het eerste nummer van zijn krant werd wellicht gepubliceerd begin januari 1667 (Gent, Universiteitsbibliotheek). 